\title{
ARTE-EDUCAÇÃO DESCOLONIAL: FORMAÇÃO DE PROFESSOR DE ARTE PARA UM TRABALHO DOCENTE MEDIADOR
}

\author{
DECOLONIAL ART-EDUCATION: ART TEACHER TRAINING FOR A MEDIATING TEACHER WORK
}

\author{
Marcos Antônio Bessa-Oliveira ${ }^{1}$
}

Submetido em: $17 / 11 / 2019$

Avaliado em: 24/04/2020

Aprovado em: 23/02/2021

\section{RESUMO}

A proposição de diálogos entre saberes, como argumenta Boaventura de Sousa Santos (2010), a partir de uma ecologia de saberes, por exemplo, é uma alternativa para a emergência de conhecimentos e saberes "desconhecidos" pela ciência para se constituir como saber superior. Baseado na lógica cartesiana, "penso, logo existo", o saber científico moderno constituiu-se como hegemônico sem dialogar com saberes subjetivos porque aqueles supostamente não pensam. Logo, a padronização do conhecimento, igualmente de arte, de cultura e até mesmo de educar (produção de conhecimentos), única e exclusivamente através da ciência que domina a escrita como modos prioritários de produção de saber, acabou por desqualificar os conhecimentos que emergem de saberes subjetivos onde escrever, crer, ser, sentir e saber, igualmente o de fazer e produzir conhecimentos não desvinculam razão e emoção. Considerando este argumento, a fim de evidenciar que por meio da Arte é possível produzir conhecimentos pela própria arte, especialmente se levarmos em consideração que a Arte é também uma disciplina que atua no saber transdisciplinar (disciplinar (SANTOS, 2010)) das Universidades, que a Arte é tão saber quanto qualquer disciplina nas Escolas e Universidades, este artigo pretende discutir a Formação de Professores sensíveis aos conhecimentos subjetivos como única alternativa para reconhecimentos de saberes múltiplos para desenvolvimento de um Trabalho Docente mediador. Quer dizer: baseado numa argumentação da descolonização do ato de educar, rediscutindo a subjetivação (padronização) de arte, de cultura e produção de conhecimentos ainda na atualidade proponho argumentar acerca de uma prática mediadora na Formação de Professores para o desenvolvimento de um Trabalho Docente em Arte que horizontalize os saberes, os fazeres, o ser e o sentir arte, cultura e conhecimentos exteriorizados pela imposição colonial do século XVI e presente ainda hoje através da colonialidade do poder instaurada com o advento da globalização no século XX. Ao certo, para tanto, me serão úteis reflexões descoloniais fronteiriças contramodernas que emergem em contextos onde a Formação de Professor e o Trabalho Docente, igualmente a compreensão de arte, de cultura e de conhecimentos estão quase na totalidade baseados na cientificidade da História da Arte no Ensino de Arte para descolonizar as fronteiras impostas por sistemas da Arte.

PALAVRAS-CHAVE: : Arte. Cultura. Conhecimento.

\footnotetext{
1 Professor do Curso de Artes Cênicas (Graduação), na Cadeira de Artes Visuais, e do Programa de Mestrado Profissional em Educação PROFEDUC da Universidade Estadual de Mato Grosso do Sul UEMS na Unidade Universitária de Campo Grande UUCG - Brasil. Doutor em Artes Visuais pelo IA-Unicamp, Mestre em Estudos de Linguagens e Graduado em Artes Visuais Licenciatura Habilitação em Artes Plásticas pela Universidade Federal de Mato Grosso do Sul. É líder do Grupo de Pesquisa NAV(r)E Núcleo de Artes Visuais em (re)Verificações Epistemológicas (certificado pela UEMS/CNPq que pode ser acessado em: dgp.cnpq.br/dgp/espelhogrupo/1456348756496114); é membro dos Grupos de Pesquisas: NECC Núcleo de Estudos Culturais Comparados (UFMS/CNPq), Grupo de Pesquisa Estudos Visuais (UNICAMP/CNPq) e do Grupo de Pesquisa O PROCESSO IDENTITÁRIO DO INDÍGENA DE MATO GROSSO DO SUL: ANÁLISE DOCUMENTAL E MIDIÁTICA DA LUTA PELA TERRA - UFMS. Atualmente desenvolve Pesquisa de Pós-doutoramento na UFMS, no Programa de Pós-Graduação em Estudos de Linguagens, na FAALC. ORCID iD - http://orcid.org/0000-0002-4783-7903. Correio eletrônico: marcosbessa2001@gmail.com
} 


\begin{abstract}
The proposition of dialogues between knowledge, as Boaventura de Sousa Santos (2010) argues, based on an ecology of knowledge, for example, is an alternative for the emergence of knowledge and knowledge "unknown" by science to constitute higher knowledge. Based on Cartesian logic, "I think, therefore I am," modern scientific knowledge has been constituted as hegemonic without dialogue with subjective knowledge because those supposedly do not think. Therefore, the standardization of knowledge, equally of art, culture and even of educating (knowledge production), solely and exclusively through science that dominates writing as a priority mode of knowledge production, eventually disqualified the knowledge that emerges from Subjective knowledge in which to write, to believe, to be, to feel and to know, to do and to produce knowledge, does not separate reason and emotion. Considering this argument, in order to show that through Art it is possible to produce knowledge by art itself, especially if we consider that Art is also a discipline that acts on the transdisciplinary (disciplinary (SANTOS, 2010)) knowledge of Universities, which Art is as knowledgeable as any discipline in Schools and Universities, this article aims to discuss the Formation of Teachers sensitive to subjective knowledge as the only alternative for recognizing multiple knowledge for the development of a Mediating Teaching Work. I mean: based on an argument of decolonization of the act of educating, rediscussing the subjectivation (standardization) of art, culture and knowledge production still at the present time I propose to argue about a mediating practice in Teacher Training for the development of a Teaching Work in Art that horizons knowledge, doing, being and feeling art, culture and knowledge externalized by the colonial imposition of the 16th century and still present today through the coloniality of power established with the advent of globalization in the 20th century. To this end, it will be useful for me to find counter-modern decolonial frontier reflections that emerge in contexts where Teacher Education and Teaching, as well as the understanding of art, culture and knowledge are almost entirely based on the scientificity of Art History in the world Art teaching to decolonize the boundaries imposed by art systems.
\end{abstract}

KEYWORDS: Art. Culture. Knowledge. 


\section{INTRODUÇÃO - "SENTA QUE LÁ VEM HISTÓRIA! "}

"No dia em que as universidades públicas ou privadas gerirem a descolonização pedagógica, será porque os processos de descolonização que percebemos na sociedade política já contribuíram para uma mudança radical e para a dissolução da matriz colonial de poder. " (MIGNOLO, in LORCA, 2014, p. 2).

O Ensino de Arte no Brasil carrega, desde a concepção de "descoberta" da colônia portuguesa no século $X V I$, uma carga impositiva de aprender um padrão de arte para fazer igual! Ou seja, é somente no século XX que o Brasil tem "implementada" uma noção primeira de epistemologia de ensinar arte que quis pensar o ensino a partir da nossa própria situação de ex-colonizados. Antes disso toda a produção artística no Brasil esteve acercada de aprender a reproduzir para produzir uma arte que fosse resultada das relações entre um ato de educar castrador e a padronização de uma única noção de apreensão de arte, de cultura e de conhecimentos trazidos com os colonizadores.

Desde os primórdios da escola no Brasil, o ensino de Artes, disciplina denominada à vezes de Educação Artística, é tema de reflexão sobre as suas Metodologias de ensino e aprendizado, entre pesquisadores e educadores da área. Além do que, a disciplina, juntamente com o ensino escolar, sofreu várias reformulações neste processo de ensinar e em diferentes períodos de modo geral. Nesse sentido, como ilustração do que estamos dizendo, é importante historicizar um pouco a questão do ensino acadêmico no Brasil e, principalmente, no ensino de Artes Visuais - como ora também é chamada a disciplina que tanto passou por mudanças de métodos sobre ela empregados (BESSA-OLIVEIRA, 2010, p. 25). ${ }^{2}$

Tendo em vista que na maioria dos casos essa história do Ensino de Arte no Brasil já é reconhecida, não tomarei dela em concentração para argumentar acerca das questões que mais me interessam: formação de professores, trabalho docente e mediação de/em/com/por meio da arte, de cultura e de conhecimentos das diferenças coloniais que vivem em condição de exterioridade ao pensamento moderno europeu desde os processos de colonização (século XVI), especialmente do Brasil, mas também de alguns casos latino-americanos. Haja vista que "enfim, a universidade e o museu são duas instituições chaves sobre as quais se fundou e se mantém a colonialidade do saber e da subjetividade" (MIGNOLO, in LORCA, 2014, p. 2). ${ }^{3}$

Assim, como num rasante, vou passar também sobre a história do Ensino de Arte no Brasil considerando que outras publicações podem Ihes dar acesso às discussões mais detalhada e aprofundadamente a respeito. Cabe, portanto, ressaltar alguns poucos pontos dessa história que estão em concordância com minha pauta de hoje: padronização da subjetividade por meio do uso de forças diversas (religiosas) para o aprendizado de arte, que consequentemente vai interferir/no fazer e no investigar arte, desde que o Brasil é "descoberto"; depois quando querem torná-lo (o Brasil) neoclássico; mais tarde quando o querem como potência criadora artístico-cultural (sob as guardas da Corte) para o mundo também europeu ou quando supostamente acham que já tínhamos identidade artística própria (modernismo)

\footnotetext{
${ }^{2}$ Mais recentemente, após a aprovação da BNCC - Base Nacional Comum Curricular - no ano de 2017, o ensino de Arte passa por mais uma mudança de nomenclatura e até conteudista e metodológica. De Área de Conhecimento - Arte - a disciplina, como várias outras, na educação básica passa a ser componente curricular de uma das Áreas de Linguagens da Base. De certa forma, uma perda de mais de 40 anos de atividade constante para tornar a Arte Área de Conhecimentos disciplinar.

${ }^{3}$ Sobre essa colonialidade do saber nas universidades venho escrevendo faz bem mais tempo. Mas sobre os museus me arrisquei a levantar algumas hipóteses no texto apresentado como palestra na 13a Primavera dos Museus - cujo tema este ano foi "Museus por dentro por dentro dos museus" - na cidade de Maracaju em Mato Grosso do Sul na noite de 23 de setembro de 2019. Mas é evidente destacar que nunca deixei de considerar o museu peça chave nessa colonialidade sobre as histórias locais, especialmente onde as cidades são bem menores em numerário de habitantes.

${ }^{4}$ Mais detalhadamente até mesmo meu próprio livro Ensino de Artes X Estudos Culturais: para além dos muros da escola (2010) pode ser um auxílio de leitura dessas questões.
} 
até chegar à nossa condição de hoje, colonizados por diferentes geopolíticas. ${ }^{4}$

Provas dessas situações de que nossas subjetividades ficaram subjugadas a classificações e categorizações, que nos foram impostas por meio de como se ensinava arte no Brasil, são as várias práticas, hoje reconhecidas também como práticas educativas, por meio das quais fomos ensinados sobre, através e de como fazer arte. Quer dizer, vou elencar rapidamente aqui algumas práticas que sequer poderiam ser pensadas como educativas, já que estou pensando em descolonização até do ato de educar, que, de certo modo, hoje as entendo como padronização de um modo e modelo de compreender arte. Logo, são práticas que nos ensinaram forçosamente a perceber o padrão de arte europeu colonial e colonizador ainda hoje no ensinar, produzir e até mesmo pesquisar arte e de apreciá-la no Brasil.

Entre os séculos XVI e XVII, uma Educação Jesuítica usou da primazia do trabalho intelectual trazido pelo colonizador de fé em sobreposição ao trabalho manual dos povos campesinos aqui moradores. Do mesmo modo, por meio de encenação de textos teatrais religiosos, os "educadores cristãos" convenceram aos agora tornados indígenas ${ }^{5}$ da crença no Salvador "branco". Além disso, é evidente nas pinturas que retratam a época (imagem 1, por exemplo), uma subserviência em adoração desses povos indígenas aos símbolos da cultura que acabara de colonizá-los. A imagem mostra ainda, de modo bastante irônico, as várias estratégias dos próprios indígenas para acompanhar aquele ato de simbolização na cruz de madeira da salvação de seus corpos (desconsiderados) através da purificação da alma que eles também "não" tinham.

Os indígenas, no pior sentido da coisa, são tornados brancos sem sê-los. Ou seja, são transformados em fieis cristãos para deixarem de ser pagãos, mas não são, no mesmo peso e medida, salvos pelo "Salvador" branco porque não o eram daquela cor. Portanto, evidencia-se aí uma colonização/padronização da subjetividade pela fé desses povos que aqui se encontravam ao levá-los a crer que a partir daquele momento os corpos deveriam ser castigados para não viverem em pecado (natural deles). Do mesmo modo é possível dizer que os indígenas "são" tornados (enganados) reflexos daqueles que agora passavam a dominar a subjetividade também artística deles. Ora, o indígena é posto literalmente sob os pés do Salvador cristão para não se impor como corpo vivo em Natureza.

Imagem 1 - Primeira Missa no Brasil, Victor Meirelles,

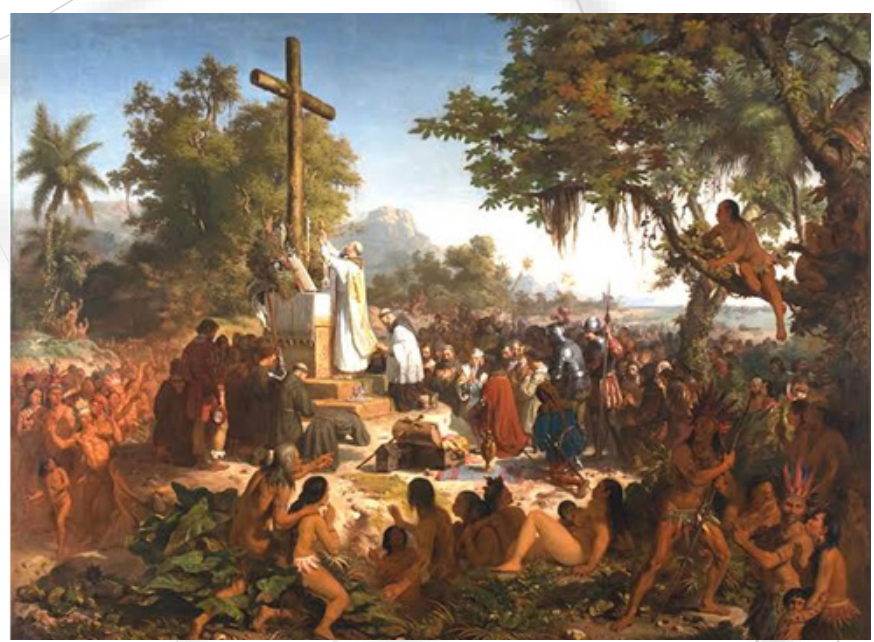

óleo sobre tela. Período Romantismo, $1861,268 \mathrm{~cm}$ x $356 \mathrm{~cm}$.

Do século XVIII até início do século XIX, uma educação Pombalina naturaliza os corpos indígenas para humanizar ainda mais os corpos europeus que eram detentores do conhecimento - da razão sobre a emoção. Com a chegada da corte Portuguesa desembarca no Brasil ainda a Missão Francesa (1816) que trazia diferentes profissionais das artes e de outras áreas do conhecimento também, a fim de fazer o país agora produzir para a Europa a "sua" arte. Fomos tornados, num piscar de olhos, ou melhor dizer num desembarcar da majestosa D. Leopoldina (imagem 2), de bárbaros dominados pelas práticas cristãs aprendidas com artistas neoclássicos em reprodutores das mesmas técnicas que se desenvolviam na Europa para ilustrar aquela cultura agora como nossa também. ${ }^{6} \mathrm{~A}$ ideia primeira era fazer-nos sentir Corte já que havíamos nos tornado o centro

\footnotetext{
5 "Tornados indígenas" porque os povos originários hoje se autodenominam, no caso dos brasileiros, como Guaranis e não índios ou indígenas como foram nominados. Segundo reza a "lenda", os povos foram nominados assim pelas construções dos brancos portugueses "descobridores" porque se equivocaram na navegação e esperavam se encontrar nas Índias ao invés das Américas.

${ }^{6}$ Nesse momento histórico da arte no Brasil é curioso observar que passamos a representar o Brasil - suas mazelas e desmazelas - por meio dos mesmos símbolos, estilos, regras, técnicas, normas e até subjetividades que vinha da Europa.
} 
da colônia, mesmo que colonizados, que dirigia o colonizador - Portugal. E é nesse período que parece gerir a confusão que enfrentamos até hoje quando pensamos nossas heranças culturais e coloniais. Da primeira fazemos questão em reforçar os traços consanguíneos com os europeus, por meio de sobrenomes, fisionomias, cor de pele e até em relação às texturas de cabelos, mas, em relação à herança colonial, fazemos questão de esquecer que também fomos forjados na morte de vários indígenas e no tráfico e escravagismo de negros que foram trazidos à força para satisfazer os primeiros brancos europeus. ${ }^{7}$

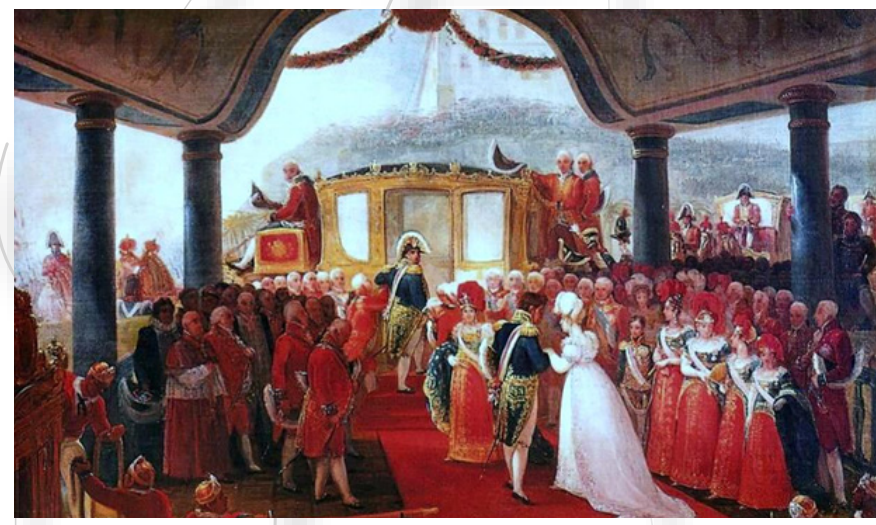

Imagem 2 - Estudo para Desembarque de Dona Leopoldina no Brasil, Jean-Baptiste Debret, óleo sobre tela. $1837,445 \mathrm{~cm} \times 695 \mathrm{~cm}$.

Entre os anos de 1822 a 1889, dentro do Período Imperial brasileiro, vigora uma educação que prepara o artista por meio de exercícios de desenhos geométricos que o fizesse alcançar a forma quase perfeita. É neste momento que o ensino, atravessado pela arte, tem certa significação porque os trabalhos estavam baseados no neoclassicismo europeu, mas com motivos brasileiros, e podiam ser tratados e aprendidos como arte brasileira dentro dos Conservatórios e Escolas que seriam criados neste período até meados dos anos 1890. Já no Período Republicano, entre 1889-1930, com a aprovação do estatuto da Escola Nacional de Belas Artes na capital
Rio de Janeiro e com outros Centros de Artes em outras localidades brasileiras, claro que também entre Rio de Janeiro e São Paulo, o ensino de Artes passa a ser praticado em escolas, mas ainda tomando como base o modelo de arte europeu. Algumas dessas escolas se espalhavam pelo Sul do Brasil também por meio da criação de Escolinhas de Artes.

Com o advento da Semana de Arte Moderna de 1922 (imagem 3) é que o brasileiro passa a acreditar, a partir de então, ser capaz de produzir uma arte "genuinamente" brasileira. As idas e vindas dos artistas do movimento modernista brasileiro entre o Brasil e a Europa, os chamados artistas do grupo do Manifesto Antropofágico, evidenciam uma criação brasileira "desobrigada" das características, especialmente europeias, mas a partir da devoração daqueles como fontes de referência e influência. ${ }^{8}$ Assim, dos fins do século XIX e princípios do século $X X$ o Ensino de Arte no Brasil tem diferentes experimentações pedagógicas - da Pedagogia Experimental às práticas de ensino permitidas pelo Regime Militar imposto no Brasil aos fins dos anos 1970 - até o surgimento na década de 1980 da proposta epistemológica Arte-Educação que faz desencadear experiências diversas no Ensino de Arte que até hoje são experimentadas nas salas de aula brasileiras.

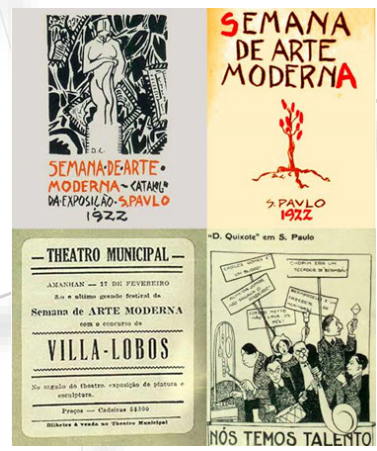

Imagem 3 - Mix de Cartazes de Divulgação da Semana de Arte Moderna Brasileira de 1922. A Semana é um movimento artístico-intelectual que ocorre entre os dias Entre 11 e 17 de fevereiro daquele ano.

${ }^{7}$ A curiosidade desse reconhecimento e desse apagamento da memória dos brasileiros das heranças consanguíneas é que, na grande maioria das vezes, muitos contemporâneos brancos (século XXI) foram gerados nas coxas das mulheres negras invadidas sem permissão e à força pelos homens brancos ou nas coxas das mulheres brancas da corte que convidavam os negros seus escravos dos prazeres da carne. Não diferentemente é possível dizer que histórias de heranças iguais a essas são possíveis de serem descritas quando falamos dos povos indígenas.

${ }^{8}$ Este fato é um caso a parte na cultura artística brasileira. Tanto o é que estou neste momento produzindo para um livro um capítulo intitulado de "Silviano Santiago/Abaporu: homens que comem gentes". Por isso mesmo não tratarei da questão detidamente aqui também. 
A partir da Arte-Educação como proposta epistemológica para o Ensino de Arte no Brasil, depois de 1980 como uma prática de construção de conhecimento que tomaria da Arte como processo educativo, bem como o que se esperava como a forma de consolidação da Arte como Área de Conhecimento, esses se deram por meio da chamada hoje "Abordagem Triangular" (1995; 1989) formulada por Ana Mae Barbosa à época. Naquele momento nascia para os professores o processo didático-metodológico que possibilitava um trabalho docente que pudesse ofertar aos estudantes um ensino e aprendizado por meio da arte que levasse em consideração o contexto do próprio estudante e professores. Entretanto, tomada como uma metodologia de ensinar arte a Abordagem foi disseminada Brasil afora ainda quase que exclusivamente baseada na História da Arte europeia. Quer dizer, experimentar, fruir e praticar, bases imperativas da triangulação para o Ensino de Arte no Brasil, além de experiências vindas de lugares estrangeiros (Europa, Estados Unidos e México) também fizeram formação dos professores de Arte no Brasil exclusivamente do parâmetro europeu de arte.

Tanto é verdade que a Abordagem nasce Metodologia Triangular e é disseminada e praticada como tal em todas as linguagens da arte ainda hoje nas salas de aula. Na Dança, na Música e no Teatro, igualmente como fora pensada para as Artes Visuais à época, a História da Arte europeia e estadunidense imperam como parâmetros para os verbos imperativos da agora Proposta Triangular educando os modos de aprender e apreender arte no Brasil. Os professores se baseiam nas histórias das respectivas linguagens artísticas para levar o estudante à reprodução da arte de tempos remotos a partir da chamada releitura das obras artísticas como se essas pasassem, a partir de então, a serem obras de estudantes que habitam o século XXI, mas que, pelo visto, continuam sem produzir uma arte do/no agora. Isso não Ihes parece ainda uma colonização da subjetividade desses estudantes?

Os professores continuam, na sua grande maioria, ainda hoje sendo formados nas universidades com referência na Teoria e História da Arte da Europa e/ou dos Estados Unidos. Logo, ainda hoje se têm um padrão de arte sendo ensinado aos futuros professores da educação básica nas universidades e, pior ainda, continuam dando cursos de Formação Continuada, aos já formados, com perspectiva histórico-acadêmica da arte europeia e estadunidense. Portanto, é possível esperarmos prática diferente do professor que está "educando" na educação básica brasileira? Sobre a Arte-Educação depositou-se as esperanças de que "estas tendências garantirão para a Arte-Educação o papel de transmissor de valores estéticos e culturais no contexto de um país do Terceiro Mundo" (BARBOSA, 1989, p. 182), mas esqueceu-se de questionar baseado em que padrões de "valores estéticos e culturais" estariam ancoradas essas transmissões por meio da Arte-Educação, ou ainda por meio da Arte ou da Educação pensadas separadamente como áreas disciplinares. Assim, neste ponto, percebe-se que o Brasil continua praticando uma Arte-Educação ou uma arte e um ato de educar mediados pelo padrão de subjetividade da arte, de cultura e de conhecimentos construídos pelos europeus ou pelos estadunidenses.

Afirmo essas questões até aqui por perceber que a arte, nas suas diferentes práticas - pedagógicas, de pesquisas teóricas sobre a arte ou na arte por meio da prática docente -, igualmente nas suas múltiplas linguagens, continua sendo postulada também nos padrões edificados na lógica cartesiana cientificista moderna e nos modelos construídos pelo pensamento hegemônico de raça, classe e gênero, mas igualmente no padrão de fé cristã ou em línguas reconhecidamente hoje como "universais" e oficiais. Pois, como posso afirmar na esteira de Walter Mignolo (2014) já suscitado aqui, de que algumas instâncias são mantenedoras dos padrões estéticos na arte; outras são defensoras do poder político na arte; e que algumas são hegemonias no fazer artístico, porque o autor vai dizer que, contudo, são as universidades e os museus que seguem e, cada um na sua situação institucional de manutenção da ordem educacional ou na linhagem histórica e geográfica da arte, respectivamente, que continuam reforçando a insistência do "educar" como a salvação ou o tempo histórico como melhor característica, porque ambos, museu e universidade, fundaram e fazem a manutenção da colonialidade do saber e do fazer arte e da subjetividade artística ainda na contemporaneidade.

\section{DESENCADEAMENTO - MEDIAÇÃO COMO PRO- CESSO DE FORMAÇÃO}

Pensar descolonialmente significa desatrelar-se dos pressupostos da epistemologia moderna baseados na diferença entre sujeito 
cognoscente e objeto a conhecer. Quando, nas propostas de tese se lê "meu objeto de estudo é X" e "meu método é Z", sabemos que estamos em plena colonialidade do saber (MIGNOLO, 2014, p. 3).

A pergunta principal que norteia as reflexões neste texto é: como a arte pode ser geradora de conhecimentos a partir da própria arte? Antes de tudo, não estou propondo que tomemos da arte como uma "coisa" distinta do mundo ou distante de tudo e de toda realidade. Como se a arte fosse uma espécie de "ser" inanimado ou mesmo animado. Igualmente, embora vá, em alguns momentos, parecer que sim - conquanto também já devesse achar que se necessita fazê-lo - não vou propor a arte como um fazer ou uma disciplina superiora aos demais fazeres e conhecimentos disciplinares presentes nas escolas e universidades de modo geral. Afinal, não foi o saber disciplinar moderno quem salvou os saberes outros. Outra questão que não poderá parecer que minha reflexão está privilegiando é que me valho único e exclusivamente de padrão (modelo), de linguagem específica (Artes Visuais, Dança, Música ou Teatro, pensando nas linguagens oficiais institucionalizadas), ou em artista específico ou mesmo de elementos formais para propor esta como uma reflexão para a Formação de Professores de Arte que desenvolvam um Trabalho Docente mediador de saberes como conhecimentos com, através e pela arte.

Essas reflexões também não são teorizações acerca de teóricos e teorias migrantes ou migradas para o contexto do qual falo, Mato Grosso do Sul, Brasil, América Latina - para construir uma metodologia melhor de ensinar Arte que deve reverberar por esses contextos diversos reproduzindo conhecimentos, culturas, subjetividades e artes de lugares longínquos -, mas emerge como um pensamento outro que ocupa a exterioridade do pensamento moderno edificado no século XVI. Logo, minha discussão ocupa um lócus enunciativo que, além de grafar-se literalmente na fronteira - Brasil/Paraguai/ Bolívia -, ainda está sob a mesma égide geo, ego e teológica de construção do pensamento ocidental para a produção de conhecimentos, para a construção do conceito de raça e do mesmo modo para o fortalecimento cada vez mais de determinada classe, bem como para definição de um padrão do ser-subjetivo. Assim, estarei aqui propondo uma construção de conhecimento que não se inscreve nas referências teóricas citadas como aportes teóricos, mas, pelo contrário, estou articulando epistemologicamente um conhecimento, ou uma forma outra de produzir conhecimento que está se erigindo por meio desse lócus enunciativo como maneira de reflexão para construção de uma mediação de saberes que ocorre a partir da exterioridade dessa especificidade (minha corpo-política) biogeográfica. Logo, descolonialidade aqui não "é só uma opção de conhecimento, uma opção acadêmica, um domínio de 'estudo', mas uma opção de vida, de pensar e de fazer" (MIGNOLO, 2017, p. 31).

Assim, estas reflexões transversalizarão à pergunta primeira levando em consideração a Arte como disciplina nas escolas ou universidades para além dos conteúdos de História e Teoria da Arte ocidental e universal nas respectivas linguagens. Do mesmo modo essas reflexões não estarão concentradas em usar da arte e seu suposto, e sempre, "colorido" - como se a arte não tratasse de desgraças humanas também - para compor disciplinas como a História (que usa da progressão temporal para ilustrar fatos), a Biologia (que a arte serve à ciência porque dá vazão e visão aos órgãos internos do corpo humano a partir da ilustração de forma e conteúdo daqueles), para a Matemática (que usa dos elementos gráficos, muitas vezes realizados sem arte alguma, mimeografados e/ou xerocopiados), para compor seus conjuntos numéricos e mais nada. $\mathrm{E}$, por último, mas ainda muito pior, é o uso que as escolas e universidades ainda fazem da Arte para ressaltar uma produção artístico-cultural em detrimento de muitas outras. Neste último caso, reforçando os usos da arte pela História (cronológica), pela Geografia (de um ou dois lugares privilegiados pelo tempo), pela Língua Portuguesa por meio da superioridade da escrita sobre a imagem, do uso da Biologia, afinal, esta é ciência e a arte não, e pela Matemática que considera o conjunto sempre das perfeitas formas como melhor. Tudo isso reforçando sempre como maior e melhor determinada técnica de produzir arte, de ensinar arte, de pesquisar arte e de trabalhar com, através e pela arte.

Igualmente a escola insiste em reforçar as diferenças entre as culturas ao ressaltar as etnias indígenas no dia 19 de abril ou as referências africanas no mês de novembro evidenciando a extravagância/exuberância dessas em relação às concordâncias das culturas europeia ou estadunidense. Faz muito tempo tenho tentado reafirmar que tratar de uma cultura em um dia ou mês especí- 
ficos não fizeram dessas culturas respeitadas na sociedade machista, preconceituosa e religiosa que temos no Brasil. Do mesmo modo é possível reafirmar que esse "reconhecimento" promovido pelos currículos escolares ou universitários, preparados por homens brancos, não fizeram outra coisa a não ser reforçar o reconhecimento dessas como culturas originárias da formação atual brasileira, mas como inferiores. Já do contrário, ambos, escolas e universidades, continuam reforçando heranças culturais, políticas, econômicas e sociais vindas da Europa longínqua dos tempos das civilizações.

A fim de dar vazão àquela pergunta, ainda que compreenda que será impossível sanar a questão na sua totalidade, afinal vou tratar da arte nas suas diversalidades de saberes e fazeres, bem como a partir de pedagogias como multiplicidades de práticas de construções de conhecimentos (BESSA-OLIVEIRA, 2019, texto no prelo), quero propor esta articulação reflexiva como prática de arte-educação descolonial para a formação de professores de Arte - que são para mim artistas-professores-pesquisares (BESSA-OLIVEIRA, 2016) capazes de desenvolver um trabalho docente mediador entre diferentes conteúdos de arte (disciplinar ou não), estudantes (dispostos e aos indispostos corpos abertos aos saberes alheios) ${ }^{9}$ e escolas e ou universidades, bem como de espaços formais e não-formais que constroem conhecimentos desconhecidos pelo conhecimento disciplinar.
Estou pensando nestas reflexões em professores em formação, para atuação nas escolas (os universitários graduandos ainda nos diferentes cursos de licenciaturas) e/ou penso naqueles que futuramente também possam atuar no ensino universitário (professores em estágio de pós-graduação nos diferentes níveis: especialização, mestrado e de doutoramento) e até mesmo penso para articular essas várias coisas em "formação de professor" e no "trabalho docente" para os atuais/atuantes professores de universidades que compreendam o conhecimento, ou melhor, a Educação para além de um ato "castrador" de educar disciplinar a quem supostamente não tem aquela educação qualificada na escrita, na leitura e/ou no domínio do conteúdo conduzido pelo professor como sabedor soberano. Logo, essas reflexões vão se articular para responder à questão primeira evidenciando que a arte pode ser geradora de conhecimentos a partir da própria arte se esse conhecimento da arte for mediado por meio de um "Arte-mediador" (SANTOS; BESSA-OLIVEIRA, 2018) ${ }^{10}$ com formação e informação e com disponibilidade que desenvolva um trabalho docente compreendido na própria arte como mais um dos saberes em diálogo (SANTOS, 2010) dos conhecimentos disciplinares presentes nas escolas e nas universidades.

Para compor esta articulação reflexiva, que já se dá como ato de proposição de arte-mediação como educação descolonial, haja vista que não tem no presente

${ }^{9}$ Esta disponibilidade e/ou indisponibilidade dos corpos dos estudantes está e deve, de uma vez por todas, ficar assim compreendida: na ótica cartesiana: 1) o estudante que deve ter o corpo sempre disponível ao professor de Arte é um estudante passivo que obedece, logo é o estudante disciplinado apto a aprender; 2) o estudante que não tem o corpo disponível ao professor de Arte, por conseguinte, é o indisciplinado, o burro que deve ser castigado no canto da sala. Na lógica descolonial: 1) ao certo, quando reforço à ideia de corpos disponíveis ou indisponíveis ao professor de Arte, especialmente nas aulas em que o trabalho corporal é condição de ocorrência dessas, não estou argumentando a favor ou contra a disciplinaridade ou indisciplinaridade de estudantes: não é a questão o estudante supostamente não apto a aprender e o estudante que se torna "o bagunceiro". Mas, que se registre para compreender definitivamente, estou argumentando do Trabalho Docente que não se realiza porque os estudantes não estão disponíveis/dispostos para aprender e/ou apreender um conteúdo que não condiz com a realidade desses estudantes. Ou seja, aquele trabalho docente que é desvinculado do contexto escolar do aluno porque o professor está sempre vinculado às formas técnicas e à História da Arte como únicos conteúdos. Logo, o professor, porque teve uma Formação Docente disciplinar e conteudista, ou por puro despreparo ou comodismo mesmo, continua forçando, reforçando e esperando corpos disciplinados e disponíveis (dos estudantes) para a realização do seu Trabalho Docente indecente de deformar corpos indisponíveis para a História da Arte, por exemplo, mas disponíveis para as suas realidades cotidianas nas ruas, bairros e cidades que têm memórias e histórias locais suas. Por último, o professor disciplinado conteudista que espera disponibilidade constante de corpos dos estudantes deve, nesta lógica de reflexão descolonial, trabalhar com pedras que são imóveis e estarão sempre disponíveis às suas mesmas marretadas cotidianas. Mas um alerta: até as pedras, dependendo da pancada que se der nelas, podem revidar mostrando indisponibilidade!

${ }^{10}$ Este conceito de Arte-mediador se refere a uma pesquisa de dissertação de mestrado em desenvolvimento hoje no PROFEDUC - Programa de Pós-Graduação Mestrado Profissional em Educação, da UEMS-UUCG - da acadêmica Kelly Queiroz minha orientanda. 
nada pronto, me valho do pensamento descolonial biogeográfico fronteiriço (BESSA-OLIVEIRA, 2017) - que tem emergência a partir do que tenho nominado de Estudos de Culturas (BESSA-OLIVEIRA, 2019a) - em constante transladação com diferentes e variados saberes e conhecimentos (disciplinares ou não-disciplinares) em evidência nos e dos próprios corpos dos professores, estudantes e instituições de ensino e aprendizagens da história e na atualidade. A partir desta articulação proposta para a construção da reflexão, além de vários autores hoje catedráticos nas escolas e universidades acerca do ensino de Arte no Brasil - especialmente daqueles que defendem a autonomia das culturas como geradoras de saberes a partir de sua própria arte, cultura e conhecimentos empíricos e específicos - vou me valer também de pesquisadores que estão subsidiados pelo pensamento descolonial latino-americano, brasileiro e local (Mato Grosso do Sul), erigidos de dentro das fronteiras impostas pelo pensamento moderno, ainda hoje, em muitos casos, desconhecidos e desconsiderados pelo saber disciplinar instalado nas escolas e universidades brasileiras, por exemplo, mas não unicamente.

Logo, a questão é que essas reflexões estão ancoradas na história da Educação por meio da arte no Brasil, igualmente acerca da história do ensino de Arte brasileiro para fazer evidenciar as questões que não deram certo, mas que se fazem presentes ainda hoje por meio da implementação da BNCC (2017), por exemplo, para tratar de uma descolonização da educação, do ensino de Arte que devem promover "formação" (será?) de professores para o desenvolvimento de um trabalho docente mediador. Portanto, a história me é fundamental para reafirmar que determinadas coisas não deveriam mais ser refeitas, mas também para reforçar que outras foram já experimentadas e são tratadas como coeren- tes até hoje. Pois, a única forma de fazer descolonizar o pensamento ainda parece ser, como afirmou Walter Mignolo, aprender a desaprender para reaprender por meio de desprender-se da razão moderna para ser, sentir, saber a fazer como tenho ressaltado.

Como dito antes, quero, a partir desses autores, edificar um conhecimento que emerge da condição de fronteira como lugar de exterioridade aos processos de homogeneização defendidos pelos projetos modernos e pós-modernos de produção de conhecimento, de arte, de cultura e de corpos em atuação nas sociedades. Desse lugar como lócus enunciativo epistemológico não me interessam rótulos acadêmico-disciplinares que mantém e continuam construindo binarismos, ainda que com boa vontade, para reconhecer uns em detrimentos de outros. Popular versus erudito; histórico versus não histórico; centros versus periferias, entre outros que acabam por reforçar a manutenção de pensamentos que privilegiam mais as situações de diferentes culturas do que as condições de diferenças culturais (MOREIRA; CANDAU, 2013), ou colônias que os lugares, sujeitos e conhecimentos têm. Quero dizer, reforçar rótulos acadêmico-disciplinares, como certos de tal ou de outros modos, é continuar dando crédito a padrões, mesmo que percebido agora por aqueles que sempre estiveram sob as brumas da colonialidade. Compreendo que nesta opção de vida - o meu pensamento é diuturnamente trabalhado para se descolonizar - opto pelo conhecimento que atrave(r)ssa ${ }^{11}$ meu próprio corpo (minha corpo-política) bio-geo-gráfico como forma de perceber meu corpo-mundo.

Ou seja, um pensamento que faz visível a geopolítica e corpo-política de todo pensamento que a teologia cristã e a egologia (e.g.

\footnotetext{
${ }^{11}$ Essa ideia está vinculada à noção de que as coisas não nos atravessam exclusivamente os corpos. Ou seja, entendendo como atrave(r)ssamento às coisas que nos entram em contato com o corpo, a memória, a história, nossa subjetividade; é possível dizer que tudo isso, quando do contato com o diferente (nós ou outra pessoa qualquer) faz também produção de sentidos outros e múltiplos. Assim, atrave(r)ssar está para a ideia de que uma coisa que nos "atinge" - nossas subjetividades -, essas, por sua vez, também fazem produzir uma narrativa outra, por isso versa de falar ainda que grafado aqui com dois "ss" para não retirar o sentido também de atravessamento. Pois, há ai também um atravessamento do que é da ordem de outros sentidos que nos chegam, mas, do mesmo modo, haverá a produção de sentidos novos graças às nossas subjetividades. Atravessar e atrave(r)ssar também podem ter sentido de se "ver" algo que "atravessa" e "versa" sem pedir licença para fazê-los; algo que tem no seu sentido de atravessar e versar um apelo de perversidade, como algo que nos contata (o "outro" em contato conosco) a fim de fazer o mal, mas também quem sabe um mal que acaba por fazer um bem; pode ser algo que provoca a atração do que está de dentro do corpo/subjetividade para vir para fora, exposição, por exemplo, de sensações camufladas; atravessar e atrave(r)ssar podem ser também inverter já que uma coisa que nos contata é transformada e tornada outra; por que não então poderia ser a segunda o inverso da primeira!
} 
cartesianismo) ocultam. Portanto, se o ponto de origem do pensamento/sensibilidade e do fazer fronteiriços é o Terceiro Mundo, e se suas rotas de dispersão se realizaram através de quem migrou do Terceiro para o Primeiro Mundo, então o ser e o fazer, habitando as fronteiras, criou (sic) as condições para ligar a epistemologia fronteiriça com a consciência imigrante e, em consequência, desvinculá-la da epistemologia territorial e imperial baseada nas políticas de conhecimento teológicas ( $R e-$ nascimento) e egológicas (Ilustração). Como é bem sabido, as políticas teo- y ego-lógicas do conhecimento se basearam na supressão tanto da sensibilidade como da localização geo-histórica do corpo. Foi precisamente essa supressão o que tornou possível que a teo-política e a geopolítica do conhecimento fossem proclamadas universais (MIGNOLO, 2017, p. 16-17).

Do mesmo modo, como estou propondo uma arte-mediação em educação, especialmente no ensino por meio da arte, para consolidar estas reflexões me valerei dos meus próprios fazeres como artista-professor-pesquisador, já que estou em atuação nos âmbitos que devem formar professores para desenvolvimento de um trabalho docente (decente) nas escolas e nas universidades. Assim, vou lançar mão, igualmente, das experivi- vências (BESSA-OLIVEIRA, 2019b) dos meus orientandos de graduação e da pós-graduação, dos membros do NAV(r)E na UUCG da UEMS que são também artistas-professores-pesquisadores em formação para atuação em diferentes contextos educacionais promovendo formação também por meio, com e pela arte. ${ }^{12}$ Do mesmo modo, quero por em articulação, para construção destas reflexões de uma arte-medicação em educação descolonial, como mediação no Ensino de Arte, para a formação de professores que desenvolvam um trabalho docente a partir da mediação de saberes e/ou conhecimentos através, com e pela arte, as experivivências que serão trazidas pelos e pelas acadêmicos(as) do $3^{\circ}$ ano do curso de Artes Cênicas - Licenciatura - turma 2019 da UUCG da UEMS durante o semestre letivo na disciplina de Arte Educação (ARED) em decurso de julho à dezembro deste ano. ${ }^{13}$

\section{SUBJETIVIDADE DE QUEM? DA ARTE, DO SUJEITO OU DOS DISCURSOS SOBRE AMBOS?}

\begin{abstract}
A Pedagogia do Oprimido não é uma pedagogia para o oprimido ou um roteiro que pessoas solidárias e de boa vontade devem usar para libertar o oprimido. Ao contrário, é uma pedagogia que permite ao oprimido extrojetar de dentro de si e, por ele mesmo, o opressor a fim de resgatar seu ser-livre e plasmar uma história na qual a prática seja a liberdade e a
\end{abstract}

${ }^{12}$ Cabe explicar porque já me referi mais de uma vez ao "através" e/ou "por meio", o "com" e "pela" arte como "metodologia" para se pensar na arte-mediação na educação como mediação de um ensino-aprendizagem de Arte na atualidade. Primeiro porque quando se fala em ensino de Arte por perspectiva como estou pensando, descolonial biogeográfica fronteiriça, esta não é um processo de "educar" castrador. Em segundo lugar porque levo em consideração que por meio da Arte é possível mediar conhecimentos atravessados e atrave(r)ssados pela arte, é possível mediar conhecimento por meio da arte, bem como é possível mediar conhecimento pela a arte e porque é possível mediar conhecimento com a arte. Quero dizer com isso que ora o conhecimento se dá na arte como prática artística (através); ora o conhecimento é construído usando da arte (por meio) como conteúdo; ora a arte serve como mecanismo de construção dos conhecimentos (pela) história, geografia, gastronômicos, políticos, econômicos, culturais e sociais; ora a arte é demonstração de conhecimentos (como) construídos a partir da própria arte. Assim, é possível perceber, nesta articulação, que o conhecimento mediado abre várias portas que o conhecimento conduzido/impositivo acaba por fechar e domesticar subjetividades; já que este último não percebe a arte local como produção artística, cultural e de conhecimentos. Por fim, sobre a questão, é evidente que fica compreendido que não se trata de uma manipulação teórica de referências moderna ou pós-moderna, mas de uma transladação entre o corpo, a arte e a subjetividade/sensibilidade biogeográfica. Sobre este ponto ainda cabe a leitura do texto (BARRETO; BESSA-OLIVEIRA, 2018, p. 37-48) em que discutimos modos de pesquisar na/com/da arte.

${ }^{13}$ Estas mesmas articulações estão se dando enquanto trabalho avaliativo para a construção de reflexões do conceito de Arte-mediador junto ao trabalho de escrita dos acadêmicos da disciplina em questão que deverão apresentar discussões epistêmicas acerca de suas práticas, a partir dos aportes teóricos e aulas ministradas, enquanto futuros docentes e/ou enquanto estudantes da educação básica ou universitária no ensino e aprendizagem de Arte. 
dialog-ação de todos com todos, prática que torna menos difícil a solidariedade, a fraternidade e o amor (BOFF, 2005, p. 7).

Então de que arte podemos falar quando pensamos produção de conhecimentos por meio da arte? $\mathrm{Na}$ arte tem, ou melhor, nos discursos sobre a arte têm uma alegação de que há uma subjetivação empírica aos contextos de emergência dos fazeres artísticos. No entanto, parece que se formos tomar o discurso, quer dizer, compreender o discurso contado por meio e através da História da Arte, comumente porque é o discurso da História da Arte o mais discriminado e utilizado nas escolas e nas universidades brasileiras - salvaguarda se não for a nível universal que a História da Arte reina como "única" narrativa sobre a história da produção artística ocidental - parece que tal subjetividade intrínseca à arte está circunscrita, na verdade, a um padrão de sujeito, de línguas, de fés, de história, de memória, de produção de conhecimentos e de um lugar geográfico específicos.

Vou argumentar acerca desta questão porque não vou defender os padrões de arte, de cultura e de conhecimentos estabelecidos pelos discursos sobre arte. Pois, se são discursos que padronizaram o sujeito, a história, a memória e um lugar como melhores, que consequentemente estão normatizando tudo a partir de imposições de forças políticas, de ideias equivocadas de democracia e de direitos para alguns, logo, é possível dizer que se espera uma subjetividade de arte igual para a coletividade e em todos os corpos humanos. Ou posso dizer, espera-se - normaliza-se por meio de discursos impositivos - uma compreensão, porque isso não pode ser definido como sensação pela arte, do que se definiu como padrão de arte. Assim, evidencia-se como mais uma questão a ser debatida neste trabalho: de que subjetividade se fala na arte, que considera um modelo de arte histórica para a promoção/reação/apreciação nos corpos da atualidade, com a arte dessa "tal" subjetividade ${ }^{14}$

Há possibilidade então de haver subjetividades?

A partir daí, na fronteira, habitar a exterioridade torna possível a opção descolonial, o que nos permite entender como uma opção entre outro qualquer projeto que se considere uma verdade única. Da exterioridade, a série de processos globais de reconfiguração da ordem ou "desordem" política, econômica e social é interpretada de outra maneira. As decisões de países e indivíduos são tomadas em relação a esses processos globais e podem estar em consonância, descontentamento ou abertamente contra um ou mais deles. Nas primeiras décadas do século XXI, a heterogeneidade histórico-estrutural dos processos globais assume a forma de três configurações, cada uma das quais se torna uma opção: re-ocidentalização, des-ocidentalização e descolonialidade ou a opção descolonial (GÓMEZ, 2014, p. 11). ${ }^{15}$ (Tradução livre mi-

\footnotetext{
${ }^{14}$ Aqui estou pensando a partir de um corpo - nunca sobre algum corpo (NOLASCO, 2019) - que vive em condição de fronteira exposta pela ideia de interioridade moderna. O corpo da exterioridade que não é enquadrado na categoria de humano, por exemplo, construída pelo projeto moderno europeu: macho fálico, eurocêntrico, rico, branco, cristão, falante de línguas oficiais e dominador do conhecimento científico e, ainda por cima, que fora tornado humanitas.

15“Desde haí, en el borde, hatibar la exterioridad hace posible la opción descolonial, lo que permite ensiguida enteder como una opición entre otras todo proyecto que se autopresente como verdad única. Desde la exterioridad se interpreta de otra manera la serie de procesos globales de reconfiguración del orden o "desorden” político, económico y social. Las decisiones de los países y de las personas se toman en relción con esos procesos globales y pueden estar en consonancia, disconancia, o abiertamente en contra de uno o varios de ellos. En las primeras décadas del siglo XXI, la heterogeneidad histórico-estructural de los procesos globales toma la forma de tres configuraciones, cada una de las cuales se convierte en una opción: la re-occidentalización, la des-occidentalización y la descolonialidad o la opción descolonial” (GÓMEZ, 2014, p. 11)
} 
nha) (Grifos meus). ${ }^{16}$

No dicionário, um dos canais mais básicos de explicação de conceitos e termos presentes na cultura brasileira, mas respeitado e muito considerado pelos pesquisadores linguistas, subjetividade é "1 Caráter ou qualidade de subjetivo. 2 FILOS[OFIA] Aquilo que se relaciona unicamente a um indivíduo, sendo inacessível a outrem. 3 Característica de todos os fenômenos psíquicos que se relacionam ao próprio indivíduo e considerados por ele seus" (DICIONÁRIO MICHAELIS, 2019, online). Quer dizer: é individual à cada ser humano e é intransferível, não pode ser manipulado de acordo com o bel prazer de determinados discursos a fim de controlar o indivíduo por meio de sua própria e livremente reconhecida como tal, sua subjetividade. Assim, compreendo que controlar a subjetividade de qualquer indivíduo é fazer perder a sua própria individualidade (suposta identidade) acerca das coisas no seu corpo-mundo.

De acordo com esse argumento, então, os limites simbólicos são centrais para toda a cultura. A marcação da "diferença" leva-nos, simbolicamente, a cerrar fileiras, fortalecer a cultura e a estigmatizar e expulsar qualquer coisa que seja definida como impura e anormal. No entanto, paradoxalmente, também faz com que a "diferença" seja poderosa, estranhamente atraente por ser proibida, por se um tabu que ameaça a ordem cultural (HALL, 2016, p. 157).

E não controlar esta subjetividade é, vou defender também, descontrolar as supostas qualificações padronizadas, por exemplo, de arte, de cultura e de conhecimentos em evidência na contemporaneidade nas diferentes situações e/ou sistemas da arte no Brasil. Portanto, o que para um indivíduo é compreendido por arte, cultura e conhecimentos não pode ser compreendido, igualmente, por nenhum outro indivíduo se não se estabelece a existência de padrões, melhor ou pior, de arte, de cultura ou de conhecimentos. Ou seja, se se compreende que a arte, as culturas e os conhecimentos não podem ser normalizados por uma única perspectiva como se quis com o projeto de modernização do Ocidente no século XVI ou ainda se quer no mundo a partir do século $X X$ com a globalização, graças às diferenças, não é permissível falarmos em uma Arte, um modelo de cultura e uma única forma de produção de conhecimentos e igualmente é impossível falar de uma subjetividade coletiva. Por certo, assim, não existe nenhum tipo de ensino de arte capaz de despertar a subjetivação em determinado indivíduo utilizando-se de modelo/homogeneização de arte, de cultura e de conhecimentos. ${ }^{17}$

\footnotetext{
${ }^{16}$ Sobre esta heterogeneidade histórico-estrutural dos processos globais, para quem acreditava que a dominação sobre o mundo ocidental agora passaria às mãos do comunismo(-capitalista) chinês, porque dominam grande parte do comércio mundial, ou às mãos dos orientais árabes graças ao capitalismo-petróleo - por meio da geopolítica energética natural que esta sob suas mãos -, Pedro Gómez vai dizer que "Todos os países que até agora administraram o capitalismo historicamente pertencem à mesma etnoclasse, unida pela ideologia do cristianismo; uma etnoclasse branca, europeia e cristã, seja católica ou protestante, cristã ou secular. Consequentemente, a transição da liderança única para a China não é apenas um problema econômico e político, mas é também racial. A China é um país de cor para o imaginário branco, e desmantelar o imaginário racial é um grande obstáculo à possibilidade [...], o que não significa, muito menos, que o trabalho deva ser abandonado para desmontar e superar o imaginário racial branco que interfere em todas as relações políticas e econômicas, bem como nas trocas culturais" (GÓMEZ, 2014, p. 12). (Tradução livre minha) "Todos los países que hasta ahora han gestionado el capitalismo históricamente pertencen a la misma etnoclase, unida por la ideología del cristianismo; una etnoclase blanca, europea y cristiana, ya sea católica o protestante, cristiana o secular. En consecuencia, el paso del liderazgo único a China no es un problema sólo de tipo económico y político, sino también racial. China es un país de color para el imaginario blanco, y desmantelar el imaginario racial es un gran obstáculo para la posibilidad [...], lo cual no significa, ni mucho menos, que se deba abandonar el trabajo para desmantelar y vencer el imaginario blanco racial que interfiere en todas las relaciones políticas y económicas así como en los intercambios culturales" (GÓMEZ, 2014, p. 12).

${ }^{17}$ Não falo neste sentido de uma classificação técnico-material formal de apreciação de arte, baseada em nomes da "tradição artística", por exemplo. Menos ainda de uso e manipulação eficiente de determinados materiais plásticos. Mas falo de apreciação sensível da arte. E sensível aqui não tem a ver com beleza. Estou tentando colocar em evidência uma sensação que está relacionada às biogeografias dos sujeitos que vivenciam a arte de suas comunidades, escolares, familiares, urbanas, entre outros lugares, que têm aproximações e distanciamentos dos próprios corpos desses.
} 
A partir daí, e em retrospecto, a história da estética começou a ser escrita, e suas origens foram encontradas não apenas na Grécia, mas na pré-história.

Essa operação cognitiva constituía, nada mais e nada menos, a colonização da aesthesis [estética] pela estética; uma vez que se a sensação é um fenômeno comum a todos os organismos vivos com sistema nervoso, a estética é uma versão ou teoria particular de tais sensações relacionadas à beleza. Ou seja, não existe uma lei universal que torne necessária a relação entre estética e beleza. Esta foi uma ocorrência do século XVIII europeu. $E$ foi na hora certa. O problema é que a experiência única do coração da Europa se traduz em uma teoria que "descobriu" a verdade da sensação para uma comunidade em particular (por exemplo, a etnoclasse que hoje conhecemos como burguesia), que não é universalizável (MIGNOLO, 2014, p. 32-33)..$^{18}$ (Tradução livre minha)

Mas a subjetivação coletiva tem sido projeto no Brasil desde 1500 com o "descobrimento" do Brasil, mas é um projeto europeu para o mundo ocidental desde que se instituiu o ano Um com o nascimento do Salvador que estabelece a contagem cronológica e histórica do tempo, e em nosso caso, dos professores de Arte, tal tempo é marcado e contado por meio da produção artística. A arte é, desde então, utilizada para ilustrar uma insistente padronização de gênero, raça, classe, de fé cristã, de determinadas línguas e do padrão de produção de conhecimento, a ciência, que é acumulado através dos tempos, de um corpo como específico e que deve ser conduzido por um professor que defende esse padrão de arte, de cultura e de conhecimento europeus como soberanos por idade-tempo/localidade-norte. Esse professor, portanto, não pode ser um formador de construção de conhecimentos diversos de arte e de cultura, menos ainda pode ser um professor mediador - um Arte-mediador - entre artes, culturas e conhecimentos da diferença colonial (MIGNOLO, 2003). Pois, baseado unicamente na História da Arte, como vem mostrando a história do próprio Ensino de Arte no Brasil, do desembarque dos Jesuítas para cá, o trabalho docente tem sido o de "educar" aos brasileiros sem educação artística - ou sem aquela subjetividade pretendida/requerida para manter a continuidade da arte, da cultura e dos conhecimentos europeus - a como reproduzir até o século XXI o aprendido impositivamente e que não é universalizável. ${ }^{19}$

Naquele período, de 1500 até meados dos anos 1800 , os Jesuítas "contribuíram" para a construção de uma subjetividade arranjada a partir da "educação" da crença cristã da cultura europeia como padrão - vestindo os povos originários, fazendo entre outras coias -, e claro, tornaram as práticas artístico-culturais e/ou manuais que esses povos desenvolviam submissas às produções vindas da Europa, pois aquela era arte enquanto esta era prática artesanal; porque as produções encontradas aqui não atendiam àquele Salvador. Além de se vestirem, o que tenta acabar com o hábito de decorar as peles com cores naturais da Natureza, prática comum no uso do urucum ou do jenipapo, por exemplo, os povos indígenas foram ainda ensinados, por meio da

18 "A partir de ahí, y en retrospectiva, se comenzó a escribir la historia de la estética, y se encontraron sus orígenes no sólo en Grecia, sino en la prehistoria.

Esta operación cognitiva constituyó, nada más y nada menos, la colonización de la aesthesis por la estética; puesto que si aesthesis es un fenómeno común a todos los organismos viventes con sistema nervioso, la estética es una versión o teoría particular de tales sensaciones relacionadas con la belleza. Es decir, ho hay ninguna ley universal que haga necesaria la relación entre aesthesis y belleza. Esta fue una ocurrencia del siglo XVIII europeo. Y en buena hora que así lo fuera. El problema es que la experiencia singular del corazón de Europa traslada a una teoría que "descubrió" la verdad de la aesthesis para una comunidad particular (por ejemplo, la etnoclase que hoy conocemos con el nombre de burguesía), que no es univrsalizable." (MIGNOLO, 2014, p. 32-33).

${ }^{19} \mathrm{~A}$ referência ao universalizável dito por Walter Mignolo faz sentido neste contexto considerando que aprender a fazer, desde que o país foi "descoberto" colônia portuguesa, não garantiu lugar enunciativo à arte, à cultura e aos saberes produzidos no Brasil em contexto global. Pelo contrário, o aprendizado com europeus e mais trade com estadunidenses manteve sob repreção toda uma produção artístico-cultural que foi padronizada desde que os europeus por aqui aportaram equivocadamente. Do mesmo modo, esqueceu-se ou desconsiderou tudo aquilo que não copiava aos moldes europeus e menos ainda - destruiu-se - aquilo que fugia ao padrão imposto. 
"educação jesuítica", a responder ao teatro e a partir de encenações de cenas relacionadas ao sagrado cristão. Ao certo, considerando a ocupação jesuítica, o corpo, neste contexto, foi impedido ainda, além da cobertura das "vergonhas", para não representar manifestação cultural por meio das danças ritualísticas e/ou comemorativas e de guerras, comuns ainda hoje na cultura indígena brasileira, porque não eram coisas de Deus. Pois, mesmo que hoje já seja comum nas igrejas cristãs, é bem recente que se dança em seus rituais, mas essas danças se tornaram práticas artísticas "aos olhos" daquele Salvador.

Assim, até mesmo o movimento, ou podemos até dizer que foi mais a subjetividade corpórea dos povos originários que aqui/já viviam que foi completamente domada/dominada à padronização de subjetividade daquele corpo que a igreja cristã havia construído: um corpo branco e coberto contra o pecado, mas que vivia em pecado. Logo, se o corpo foi domesticado e teve que se enquadrar ao padrão dos corpos europeus, que com isso controla a subjetividade através do controle de movimentos, de sensações, de sexualidades, do direito ao prazer, entre outras coisas, é possível afirmar que as mesmas coisas, em relação ao Teatro e as Artes Visuais, por exemplo, também foram controladas e fizeram a subjetividade dos indígenas com reflexo a essas controladas. "E porque o "corpo" foi o objeto básico da repressão, a "alma" pôde aparecer quase separada das relações intersubjetivas no interior do mundo cristão. [...], culminando no processo da secularização burguesa do pensamento cristão" (QUIJANO, 2010, p. 12). E, seguindo a mesma lógica de compreender a deslegitimação do corpo indígena, por exemplo, provocada pela cristianização por meio da educação através da arte, tem que

O processo de separação destes elementos do ser humano é parte de uma longa histó- ria do mundo cristão sobre a base da ideia da primazia da "alma" sobre o "corpo". Porém, esta história mostra também uma longa e não resolvida ambivalência da teologia cristã sobre este ponto em particular. Certamente, é a "alma" o objeto privilegiado de salvação. Mas no final das contas, é o "corpo" o ressuscitado, como culminação da salvação (QUIJANO, 2010, p. 12).

É evidente que toda essa narrativa acerca da "educação jesuítica" aqui presente no contexto de tão jovem colonização brasileira é exposta através da impressão europeia que, na lógica cristã, salva o mundo por meio da salvação da alma. Pune o corpo por meio do castigo e da castração dos desejos. Mas não podemos deixar de registrar que essas histórias demonstram o controle de nossa subjetividade latina desde ali: o corpo latino deixa de ser considerado, já que os povos aqui residentes não reconheciam o "corpo" do Salvador cristão crucificado como norma de representação/subjetivada da relação homem e espiritualidade. ${ }^{20}$ Igualmente é certo dizer também que essa mesma impressão europeia não devia e não deve ser reverberada até hoje por meio de uma atividade docente impositiva. Quer dizer, por mais que o professor seja um adorador e até defensor de nosso "descobrimento" artísticos, graças aos europeus - reconheço o imperativo desta visão em tempos tão assombrosos como os que vivemos -, é fundamental um trabalho docente mediador do professor entre aquela história, nossa produção e até com o nosso contexto ainda hoje em relação ao corpo, a arte, a cultura e aos conhecimentos, mas também em relação à antiga afinidade entre arte versus cristandade e entre arte e outras religiosidades nem sempre reconhecidas como tais. ${ }^{21}$

Sim, entendo, e estou cada vez mais conven-

\footnotetext{
${ }^{20}$ Essa questão faz suscitarmos os projetos "Escola Sem Partido" e "Escola Sem Religião". Ainda que fossem propostas decentes, ambos não se baseariam na lógica de sem políticas-partidárias e sem religião com ideologias específicas como padrão. Pois, em um país que se diz laico ou apartidário, política e religião não deveriam ser discutidas com objetivo de proibições.

${ }^{21} \mathrm{Um}$ trabalho docente mediador em afinidade às velhas relações que foram estabelecidas por meio da arte, com religiões, políticas e sociedades, pode (re)verificar as analogias que estão ainda hoje estabelecidas entre essas: a arte não precisa estar submissa a essas relações em prol da velha política da amizade (cf. DERRIDA, 2003). Mas pode desenvolver um trabalho artístico e de produção de conhecimentos em favor de evidenciar também essas afinidades de forma política e até mesmo de apoio. A lógica maior que devemos ter em mente, ou seria bom dizer que a "razão" na qual se coloca esta reconfiguração até dessas afinidades, é que não podemos apenas substituir aquelas (religiões, políticas e sociedades) simplesmente por outras agora para não correr o risco de estabelecermos os mesmos binarismos.
} 
cido de que o conector [...] consiste em ações descolonizadoras que se apegam, como se poderia dizer, à história da arte, museus e teatro. Mas enquanto artes, museus e teatros eram codificados no Ocidente, em sua própria formação como civilização ocidental e, como tal, estavam envolvidos, conscientemente ou não, com projetos colonial-imperiais, a descolonização estética é uma das muitas maneiras de desarmar essa montagem e construir subjetividades descoloniais. A estética descolonial substitui a estética imperial, agora sujeita aos valores corporativos e de mercado (MIGNOLO, 2014, p. 52).22 (Tradução livre minha)

Pensar neste professor mediador, ou como tem pensado Kelly dos Santos (2019) no Arte-mediador, é trazer as necessárias e obrigatórias relações entre arte da história e artes de nossas ágoras que demandam, na esteira de Walter Mignolo, estéticas outras que melhor compreendam os fazeres artístico-culturais também outros que devem, igualmente e impreterivelmente estar dentro das salas de aula em convivência com o conteúdo regular euro ocidental que hoje faz nossos currículos. Logo, é possível dizer que neste contexto teremos, por conseguinte, diversalidades múltiplas em convivência e, ao certo, subjetividades diversas de apreciação, sensação em relação à arte descolonial ali em emergência. $E$ do mesmo modo em relação à arte colonial. Para desenvolver este trabalho docente descente é necessário, portanto, que o professor não seja formado com perspectiva teórica exclusivista de nenhuma corrente teórica, pois, sem abrir-se ao novo, ao diferente, um trabalho docente apenas pode ser desenvolvido de maneira castradora. Ou seja, priorizar determinado conteúdo e desconsidera uma quantidade muito maior que não é considerada para a construção daquele conteúdo que o é mais importante. Assim, uma formação de professor aberta para um trabalho docente descente considera que

No momento, a descolonialidade é uma visão e uma orientação que coexiste e coexistirá em tensão com outras visões e sistemas de ideias (o liberalismo, o neoliberalismo, o marxismo, o cristianismo, o confucionismo, o islamismo), assim como com orientações e visões disciplinares (ciências humanas e naturais, escolas profissionais, etc.). A decolonialidade é uma opção entre outras (MIGNOLO, 2014, p. 2).

Nossa história tem fatos tão horripilantes que sem uma intervenção mediadora de um Arte-mediador no Ensino de Arte no contexto brasileiro é possível acabar com uma mínima subjetividade/sensibilidade dos estudantes em relação ao fazer artístico. Agora, faço aproximação e/ou relação íntima entre subjetividade e sensibilidade a fim de oficializar que nem uma nem outra das opções em relação à arte nesta discussão têm a ver com educação estética dos estudantes. ${ }^{23}$ Do mesmo modo não estou reforçando a ideia de ensino inter, multi ou transcultural como temos pensado trabalhar nas escolas ou nas universidades. Pois, como argumentou também Boaventura de Sousa Santos, até a prática transdisciplinar no Ocidente tem total caráter disciplinar (SANTOS; HISSA, 2011) porque aquela não leva em consideração os saberes não-disciplinares para falar em movimento de transsaberes, vamos dizer assim. Esta última questão, obviamente, está relacionada com o diálogo de saberes de Boaventura de Sousa Santos que igualmente fala sobre ecologia de saberes (2010).

Não é incomum que seja assim, pois, ao

\footnotetext{
22 "Sí, veo, y cada vez me convenzo más de que el conector [...] consiste en acciones decolizadoras agarrándose, como podría decirse, de la historia del arte y de los museos, y del teatro. Pero mientras que artes, museos y teatros fueron codificados en Occidente, en su formación misma como civilización occidental, y como tales estuvieron involucradas, a sabiendas o no, con los proyectos imperiales-coloniales, la decolonización estética es una de las tantas formas de desarmar ese montaje y construir subjetividades descoloniales. Las estéticas descoloniales desplazan las estéticas imperiales, ahora sometidas al mercado y a los valores corporativos" (MIGNOLO, 2014, p. 52).

${ }^{23}$ Este ponto me é bastante caro! Educação Estética! O termo me é horripilante. Todas às vezes que leio ou ouço alguém falar em educação estética me pergunto: será que essa pessoa está consciente de que educação e de que estética esta falando? Ou será que essa pessoa leva em consideração a Educação e a Estética como venho aqui discutindo: castradoras? Todas as vezes que estabelecemos um padrão, inclusive o de subjetividade estética e de conhecimentos, estamos castrando subjetividades e saberes outros. Logo, educar esteticamente é definir um padrão de sensação que o indivíduo deve sentir.
} 
se tornar uma questão essencial, que diz respeito às incompletudes da ciência moderna, a transdisciplinaridade, ao aglutinar como moda, é trabalhada até como uma questionável possibilidade metodológica no âmbito do ensino e da pesquisa. Soa como uma deturpação da ideia da transdisciplinaridade admiti-la não como um modo de pensar, mas como uma estratégia de ensinar ou de pesquisar, quase uma técnica (SANTOS; HISSA, 2011, p. 18).

Mas toda esta questão, pior ainda, não se aproxima de um padrão histórico-geográfico de arte produzido no passado a ser desenvolvido como criatividade, por meio de cópias de trabalhos como releituras de obras clássicas, e a ser ensinado nas aulas de Arte. Este foi um ponto em que aquela episteme de Arte-educação criada nos anos de 1980 acabou por reforçar: quando a Abordagem Triangular acaba se tornando metodologia triangular para todos os professores o exercício resultante do experimentar, fruir para praticar acaba sendo, e é ainda hoje, a releitura de obras clássicas como se fossem criações. Logo, estou compreendendo nesta reflexão que sempre fomos levados - desde 1500 com os Jesuítas e com muitos casos dos professores na contemporaneidade - a copiar e fazer releituras da arte, da cultura, da história, da memória europeia e/ou estadunidense, bem como do corpo daqueles como conhecimentos a ser aprendidos nas aulas de Arte, apenas porque eram todas produções trazidas de fora. ${ }^{24}$ Como já dito, do barro à fé dos povos originários, o corpo e a cor sobre os corpos mudaram de desenhados e sinuosos e ainda coloridos, literalmente, para corpos reformados por es- truturas de ferro e tecido que inventavam curvas e cores que os europeus definitivamente não tinham. Hoje ainda podem ter graças às tecnologias que artificializam inclusive corpos de brasileiros e brasileiras.

Naquele momento da "educação" no Brasil, em que um professor de Arte, Arte-mediador atuaria para tornar melhor a aproximação das práticas artístico-culturais e dos saberes diferentes, ainda que sem desconsiderar o processo impositivo na nossa história, violento e também de diferentes outras questões coloniais, tivemos sujeitos desenvolvendo o ato de "educar" castrador e proibitivo em relação aos estudantes. Coisa ainda comum nas escolas e universidades contemporâneas: muitos professores, da educação básica aos cursos de pós-graduação, trabalham ancorados em teorias exclusivistas que delimitam o "corpo" docente. Se por um lado poderia ter havido uma relação "cordial" entre saberes e fazeres artísticos e de produção de conhecimentos e cultura para ambas as culturas ${ }^{25}$ - colonizador e colonizados - um Arte-mediador, de perspectiva mediadora entre o que é desconhecido/desconsiderado, poderia ter promovido, por exemplo, o respeito entre corpos, fés, raças e até entre os diferentes entendimentos do que os indígenas e europeus percebiam/conheciam por classe e ainda mais do que achamos que sabemos sobre gêneros. Mas infelizmente é necessário reconhecermos que "dominar" a compreensão de arte, de cultura e de conhecimentos controlando-as naquele contexto é estabelecer o controle da subjetividade que, por conseguinte, controla o próprio indivíduo - o seu próprio corpo é colocado sob controle da fé cristã, por exemplo, que o impede de ser gente, porque foi tornado humanitas pelo saber disciplinar moderno - e que por isso precisa salvar a alma ao invés do corpo.

\footnotetext{
${ }^{24}$ Essa lógica no ensino de Arte no Brasil acercou-se no fato de aquela produção ter história antiga. Logo, por isso, é evidente a presença tão contundente da História da Arte (europeia ou estadunidense) nos planos de aulas, nos referenciais curriculares e até nas propostas epistemológicas em Arte-Educação, em Arte ou em Educação nas escolas e universidade Brasil afora. Os professores aprenderam que a História da Arte é âncora que sustenta o trabalho docente bem como deve ser ensinada antes mesmo de qualquer outra relação possível com/através/por meio da arte. E assim seguimos todos com o mesmo padrão de subjetividade/sensação/apreciação em relação à arte.

${ }^{25}$ Sobre esta questão é até possível lançar mão da discussão de Jacques Derrida sobre hospitalidades e hostilidades (SKLIAR, 2005) nas culturas para as quais os teóricos e teorias migram. Ou seja, nos países periféricos as teorias e teóricos sempre encontraram lugares confortáveis (recebidos pelas universidades e universitários (docentes e discentes)) para chegar e apropriarem-se das práticas dessas culturas moldando-as a partir das suas reflexões. Quando Derrida observa esta questão está argumentando da necessária hostilidade em relação à essas migrações que corroboraria o desenvolvimento de teorias e teóricos (locais) que pensam situados epistemologicamente onde essas teorias e teóricos migrantes não deveriam chegar e reinar porque seriam também hostilizados.
} 
Nossos sentidos forma treinados pela vida para perceber nossa diferença, para sentir que fomos feitos anthropos, que não formamos parte - ou não por completo - da esfera de quem nos olha com seus olhos como anthropos, como "outro". O pensamento fronteiriço é dito de outra forma, o nosso pensamento, do anthropos, de quem não aspira se converter em humanitas, porque foi a enunciação da humanitas o que o tornou anthropos (MIGNOLO, 2017, p. 21).

Assim, é possível dizermos que, no caso do Brasil, por exemplo, o Ensino de Arte foi e ainda também segue sendo um mecanismo de cerceamento da subjetividade dos povos não reconhecidos como produtores de arte, de cultura e de conhecimentos por aqueles que (n) os classificaram de humanitas subjulgados à cultura europeia colonial. Desse modo, igualmente, a formação de professores nas universidades contribui, dando formação teórica com referenciais trazidos de fora, para o desenvolvimento de um trabalho docente "educador" castrador já que desconsidera o saber, o ser, o sentir, o fazer e os corpos dos sujeitos tornados os "outros". E porque o Ensino de Arte contribuiu e continua contribuindo com esse processo de colonização do saber? É exatamente porque ainda continua-se educando por meio de um ensino de determinada arte como padrão "organizando" - como em coleções museológicas - o currículo nas escolas e nas universidades e assim castrando as subjetividades que percebem outros fazeres artísticos como arte do ser, do sentir e do saber interiores às suas exterioridades (descoloniais), especialmente daqueles que sempre viveram em condição de fronteiras impostas pelo pensamento moderno colonial que exterioriza tudo e a todos que não se enquadram em seus padrões.

É por isso também que um trabalho docente como Arte-mediador, um professor que convive também com as diferenças e com as fronteiras enquanto condições em seu próprio corpo pode reafirmar a opção descolonial também para a Arte-educação tornar-se um Arte-mediador com um trabalho que reconheça nas diferenças e nas condições de viver em fronteira possibilidades de conviver com as diversalidades de produção de arte, de culturas e de conhecimentos diversos. $O$ trabalho docente mediador não é do tipo que se concentra no sentido das palavras ou com a descrição de determinados conceitos, de certo ou errado, usados correto ou incorretamente e pensados por determinados filósofos que não tenham vivenciado as experivivências, por exemplo, de habitar a exterioridade do pensamento moderno europeu. Logo, um trabalho docente mediador, um Arte-mediador nunca usará do livro didático como único recurso, ao menos do livro didático como normalmente ainda temos nas escolas hoje: manuais. Do mesmo jeito o currículo de um professor mediador deve reconhecer nos diferentes fazeres artísticos, periféricos e de diferentes localidades (coloniais, imperiais e subalternos), igualmente nas multiplicidades de sujeitos as relações de aproximações e especificidades que fazem das histórias locais particulares em relação às ideias hegemônicas de projetos globais.

Por isso, mediar não é educar nos moldes tradicionais como entendemos este último. Já que mediar está compreendido na ideia de que aqueles estudantes também têm um conhecimento que o professor tradicional não acessa. Ou não se permite acessar. Logo, o professor que ao certo será tratado como mediador, e que nem por isso tem menos conhecimentos, talvez deva ter cada vez sempre mais, será muito mais quisto pelo estudante que se reconhecerá no conteúdo por este professor-mediador abordado. Portanto, haveria de ser o processo de educação dado nos dois sentidos, não unicamente do professor em relação aos estudantes, como se esses últimos não tivessem capacidade de ser educados. $\mathrm{E}$ não educados para serem ensinados. Igualmente desses estudantes para aquele Arte-mediador. Mas de ter um conhecimento que não pode ser aprendido por meio, ou atravessados por conhecimentos (teorias e teóricos) vindos de fora dos contextos nos quais, por exemplo, crescem os indivíduos que estão envoltos à Natureza como espaço de convivência, nunca obediência desta em relação àqueles como homens soberanos porque dominam o conhecimento edificado pelo projeto de colonização moderno do mundo.

A universidade foi e segue sendo uma instância fundamental da colonialidade do saber. A transformação na Europa das universidades medievais (Bolonha, Salamanca, Coimbra) em universidades renascentistas estendeu-se no século $X V I$ às colônias hispânicas: a Universidade de Santo Domingo, no México, San Marcos, de Lima, no Peru, a Universidade de 
Córdoba, na Argentina. E a Harvard, nos Estados Unidos, no século XVII. Enquanto Portugal não incentivou a criação de universidades, a Espanha se autoassinalou uma missão teopolítica: o controle dos corpos mediante o controle das almas, ou seja, das subjetividades. No século XVIII, a universidade renascentista mutou-se, na Europa, na universidade kantiana-humboldtiana. Esse modelo de universidade desloca a universidade teológico-humanista dos Estados monárquicos e nasce a universidade dos Estados seculares: a ideia de cidadania e democracia conecta o controle do conhecimento ao controle da autoridade. Na América, as universidades coloniais teológico-monárquicas mutam-se em universidades seculares estatais. E se fundam outras universidades, como a do Chile, em 1862, e a UBA, em 1821. Tudo isto antes que a França e a Inglaterra colonizassem a África e a Ásia, e começasse aí a instalação de universidades kantianas-humboldtianas. Enfim, a universidade e o museu são duas instituições chaves sobre as quais se fundou e se mantém a colonialidade do saber e da subjetividade (MIGNOLO, 2014, p. 1-2). (Grifos do texto).

Assim, pode-se dizer da subjetividade relacionada ao ensino da Arte, como uma missão teopolítica consolidada por meio da educação, já que foi a instituição de universidades no mundo ocidental como um projeto de transmissão de um conhecimento, que o controle dos corpos mediante o controle das almas, ou seja, das subjetividades se fortaleceu. Igualmente é essa lógica de mundo binário que controla e que mantém o modelo de educação que temos imperante ainda nas escolas onde sequer têm estrutura para atuação decente do professor. Igualmente não é permitido ao sujeito ser quem quer que seja. Nem mesmo os banheiros, muitas vezes, são decentes nas escolas públicas ofertadas pelo estado-nação como política pública de educação: ainda falamos em banheiros não binários como os que são banheiros "Uni-sex" - para o homem ou a mulher. Porque já não falamos em banheiros plurisex? Espaços sanitários que acolham as diferenças necessárias não binárias de sexo. Mas até mesmo para falar de banheiro ainda vemos no outro o espectro da invenção moderna do que é ser gente: o outro é sempre aquele que não é - Grande Eu! O outro é sempre a representação (construção) do que o Eu se quer representado.

Como funcionam? Suponhamos que pertence à categoria de anthropos, ou seja, o que na maioria dos debates contemporâneas sobre a alteridade corresponde a categoria de "outro". O "outro", entretanto, não existe ontologicamente. É uma invenção discursiva. Quem inventou o "outro" senão o "mesmo" no processo de construir-se a si mesmo? Tal invenção é o resultado de um enunciado. Um enunciado que não nomeia uma entidade existente, mas que a inventa (MIGNOLO, 2017, p. 18).

Logo, subentende-se que o professor ainda parece se espelhar nessa lógica ressaltada por Walter Mignolo para tratar com os estudantes em sala de aula. Ou seja, o professor espera do corpo do estudante aquela disponibilidade, já ressaltada antes aqui, para transmitir-lhe um conhecimento discriminado nos referenciais curriculares e mais formatado ainda no seu plano de aulas; já que este repete aquele último sem a menor vergonha. Nesse caso, o estudante (o outro da sala de aula), já que é o professor quem é o Eu, acaba por não ter direito à voz e vez de falar, ser, sentir e saber e menos ainda fazer mesmo que por meio de uma proposta como a Triangular que ainda impera no ensino de Arte reproduzindo arte histórica por meio de cópias.

É nessa construção do outro que está baseada também as informações e formulações da subjetividade do estudante e do espectador da arte. O ensino de Arte está ancorado na ideia de que o estudante necessita aprender um padrão de arte - experimentar, fruir e praticar por meio das releituras - de bases históricas e geográficas situadas na Europa ou nos Estados Unidos para se sentir educado. Do mesmo modo o espectador precisa aprender a apreciar e compreender, por meio da lógica do "que o artista quis dizer", a arte produzida sempre relacionada ao passado histórico e à geografia que não faz parte de sua experivivência corpórea. Assim, ambos, estudantes e espectadores acabam por necessitar, mais ainda no cenário em que a arte é mais desprivilegiada quando se é produzida em solo fronteiriço (marginal), de professores-mediadores que contribuam com a aproxi- 
mação do que é construído fora do seu corpo e espaço que também são históricos e geográficos, mas, mais ainda, de exposição do que é dá ordem do seu corpo e espaço biogeográficos. Ou seja, é emergencial um Arte-mediador para fazer a fruição entre o que é da ordem do migrante e o que é da ordem da subjetividade.

A professora Kelly dos Santos (2019) tem falado em sua pesquisa de mestrado em um Arte-mediador que só o é porque ocupa o "terceiro espaço". Mas o que poderia ser esse terceiro espaço quando se fala em salas de aula e ensino de Arte? Penso, da minha perspectiva, ser o lugar/espaço do intermédio entre o estudante e o professor - que aliás dependendo da prática docente e discente pode se tornar um muro em emergência como uma fronteira que apenas separa - onde ocorre o que seriam as trocas de conhecimentos das diferenças (culturais e coloniais) entre esses sujeitos em contato. Ou seja, quando Homi K. Bhabha e Silviano Santiago falam cada um a seu modo, de "entre-lugar" (1998) e "entre-lugares" (2000), respectivamente o indo-britânico e o brasileiro, é por compreender que exatamente neste lugar é aonde vai ser colado em circulação, por exemplo, por meio e através da arte, um conhecimento/balbucio (ACHUGAR, 2006, p. 35) que o pensamento moderno disciplinar castrador e regulador desreconhece. Mas é um conhecimento que não pode deslegitimar porque não tem sequer conhecimento sobre esse.

A partir dessa ordem imposta nos sistemas de observar para apreender por meio da arte que se faz necessária a adoção da corpo-política como estratégia de reformulação até da compreensão da subjetividade própria, dirá em relação à alheia. Própria porque por muitas vezes parece que o professor, o artista e até a crítica não parecem perceber que suas próprias subjetividades são corpos sob o controle da geopolítica da arte. Alheias haja vista a noção de que estamos sempre construindo o outro a partir do que esperamos que eles sejam. Assim, a corpo-política é, na ordem de Mignolo (2008), a parte faltante da história e geografias estabelecidas pela história universal da arte, mas também do padrão de cultura e de produção de conhecimentos cartesiano. Ou seja, a corpo-política somos nós (supostamente o outro construído pela lógica moderna europeia em manutenção pela pressão capitalista estadunidense) que não fomos consultados, mencionados, lembrados e sempre somos excluídos da construção da grande narrativa universal de tradição de arte, de cultura e de conhecimen- tos que ilustram o Ocidente.

É por meio da adoção da estratégia do corpo-política que o Arte-mediador pode reconhecer os corpos indisponíveis nas escolas nas aulas de Arte, posto que os disponíveis já estarão ali presentes a fim de apreenderem. Mas ambos, corpos disponíveis e indisponíveis, igualmente o corpo-professor-Arte-mediador, estarão ali carecendo da mediação entre as diferentes corpos-políticas que têm informações, formações e, claro, subjetividades divergentes em relação à arte, a cultura e aos conhecimentos das diferenças. Imediatamente, estou pondo em evidência que o professor Arte-mediador não é um transmissor de conhecimentos melhores e superiores em relação aos que os estudantes têm. Mas reforçando que é reconhecer a diferença nas subjetividades e especificidades entre esses indivíduos da sala de aula que fará colocar em circulação uma troca - mediada: partes de si e partes dos outros sem distinção de Eu ou de outro modernos - entre o que é da ordem do currículo, do professor, da arte e dos corpos disponíveis e indisponíveis dos estudantes. Do mesmo jeito, ficará evidente à sociedade escolar que as aulas de Arte tornar-se-ão uma construção coletiva em que a atuação das diferentes corpo-políticas é que fará evidentes as diferentes biogeografias: corpos, espaços e narrativas por meios dos sujeitos (identidades e autorrepresentações) e suas geografias (lóci enunciativos) com suas formas particulares e especificas de produção de narrativas (usando da dança, do teatro, da música, das artes plásticas, da performance, do cinema ou de dentre as muitas outras linguagens e formas artístico culturais de narrar o seu mundo).

Não, não estou falando de "política de identidade", mas de "identidade em política". Não há, pois, necessidade de argumentar que a política de identidade se baseia na suposição de que as identidades são aspectos essenciais dos indivíduos, que podem levar à intolerância, e de que nas políticas identitárias posições fundamentalistas são sempre um perigo. Uma vez que concordo parcialmente com tal visão de política de identidade - da qual nada é isento, já que há políticas identitárias baseadas nas condições de ser negro ou branco, mulher ou homem, em homossexualidade e também em heterossexualidade -, é 
que construo meu argumento na relevância extrema da identidade em política. E a identidade em política é relevante não somente porque a política de identidade permeia, como acabei de sugerir, todo o espectro das identidades sociais, mas porque o controle da política de identidade reside, principalmente, na construção de uma identidade que não se parece como tal, mas como a aparência "natural" do mundo. Ou seja, ser branco, heterossexual e do sexo masculino são as principais características de uma política de identidade que denota identidades tanto similares quanto opostas como essencialistas e fundamentalistas. No entanto, a política identitária dominante não se manifesta como tal, mas através de conceitos universais abstratos como ciência, filosofia, Cristianismo, liberalismo, Marxismo e assim por diante (MIGNOLO, 2008, p. 289). (Grifos meus e do autor)

Do mesmo jeito, quando pensamos na situação brasileira, a política identitária ou as políticas de corpos, não as diferentes corpos-políticas como estou argumentando, estão situadas na geografia e na historiografia privilegiadas como maneiras de sustentação do poder instituído no passado até hoje. Igualmente, na Educação, por meio do ensino de Arte, um professor "educador" é aquele que se vale da geo, da teo e da historiografia clássicas para ressaltar a fundamental importância de continuar transmitindo o mesmo conhecimento que tem mais de 500 anos e que frequenta a formação da subjetividade dos brasileiros. Não o é diferente que os mesmos conceitos de universalização são corroborados nas escolas e nas universidades pela abstração do conhecimento por meio da ciência, da compreensão do mundo e do sujeito via a filosofia, de fé grassada na ideologia do Cristianismo, ou mesmo por meio do liberalismo governamental e no Marxismo tradicional colocados como ideologias únicas possíveis. O problema da ideologia não está na existência dela; assim como o problema da subjetividade concreta é uma razão moderna de apreender o mundo pela Arte, a ideologia peca em rechaçar as diferentes outras ideologias.

O afastamento das singularidades de "classe" ou "gênero" como categorias conceituais e organizacionais básicas resultou em uma consciência das posições do sujeito - de raça, gênero, geração, local institucional, localidade geopolítica, orientação sexual - que habitam qualquer pretensão à identidade no mundo moderno. O que é teoricamente inovador e politicamente crucial é a necessidade de passar além das narrativas de subjetividades originárias e iniciais e de focalizar aqueles momentos ou processos que são produzidos na articulação de diferenças culturais. Esses "entre-lugares" fornecem o terreno para a elaboração de estratégias de subjetivação singular ou coletiva - que dão início a novos signos de identidade e postos inovadores de colaboração e contestação no ato de definir a própria ideia de sociedade (BHABHA, 1998, p. 19-20)

Tão certa é a questão exposta que a singularidade imposta pelas classificações modernas que delimitam a atuação das subjetividades dessas no mundo ocidental não permite sequer a existência do diferente sem que esse passe pelo crivo do julgamento de quem estabeleceu as classes. Assim, insistir no padrão de identidade, de conteúdo, de linguagem, de currículo como a escola está sendo obrigada a fazer (graças à BNCC (2017), por exemplo) é reforçar na precariedade da arte, da cultura e dos saberes (que não são tidos como conhecimentos) que "transitam" nos espaços escolares. Se por um lado essa consciência das diferenças deveria desestabelecer qualquer grau de imposição dos padrões, já que os das diferenças se fazem hoje presentes nos contextos mesmo aonde não foram convidados, por outro lado há um reforço hercúleo daqueles que ainda acreditam que existe um padrão de arte, de cultura e de conhecimentos nos quais as subjetividades das diferenças devem se encaixar aprendendo-os. Assim, por meio dessa manutenção de padrões e classificações que se faz presente a negligência das subjetividades dos estudantes nas aulas de Arte ao impor um aprendizado de uma técnica específica para modelar o corpo da diferença ou uma história e geografia como lugares privilegiados de produção de arte, de cultura e de um conhecimento que deve ser reproduzido.

"A força dessas questões é corroborada pela "linguagem" de recentes crises sociais detonadas por histó- 
rias de diferenças culturais" (BHABHA, 1998, p. 20) em evidência no mundo como um todo. Entretanto, vê-se também a exaltação da diferença como peste daninha em contexto da interioridade/igualdade moderno colonial ou pós-modernidade capitalista. E essa exaltação que leva à exclusão do diferente é constante também na arte em todos os seus fazeres (artístico, pedagógico e crítico) e igualmente nos espaços que compõem o sistema da arte (museus, universidades, escolas, galerias do estado-nação e nas instituições privadas) que elevam a diferença ao lugar de dependência e que retiram os direitos daqueles que estabeleceram os supostos "direitos" aos vistos então como necessitados. Assim, "os termos do embate cultural, seja através de antagonismos ou afiliação, são produzidos performativamente. A representação da diferença não deve ser lida apressadamente como o reflexo de traços culturais ou étnicos preestabelecidos, inscritos na lápide fixa da tradição" (BHABHA, 1998, p. 20) que impõem lugar de classificação ao que é da ordem da sua diferença cultural ou colonial.

Será no poder das massas, sem raças, que as diferenças coloniais serão reconhecidas pelas raças que imperam nos sistemas da educação, da arte, da cultura ou da produção de conhecimentos. Pois, se por um lado são os corpos das massas que trabalham para sustentar o corpo de raça que desgraça e comanda, por outra perspectiva poderemos esperar, especialmente de um Arte-mediador fortalecer o corpo que trabalha para ser, sentir e saber e, assim, sim poder fazer e conviver em harmonia com seu direito de ter. Fica claro nesta questão que o corpo e o lócus enunciativo são as forças propulsoras da diferença colonial, pois é ele quem detém o poder de suportar toda a carga que é atribuída a ele e à própria alma que o pensamento moderno cristão europeu quis tanto preservar para apagar o diferente. Logo, três vivas ao corpo da diferença colonial!

\section{ALGUMAS BREVES CONSIDERAÇÕES}

A ciência, ao superar a si própria, através de processos de tradução, se enriquece de todos os demais saberes (SANTOS; HISSA, 2011, p. 19).

Entre o trabalho e a escola, o brasileiro quase sempre opta pelo trabalho. O sistema hoje imperante de educação também forma o sujeito para ser um trabalha- dor. Logo, a opção que lhes é dada é a de estudar para conseguir trabalhar. Ainda que ineficiente, já que a escola não forma mão de obra profissional e técnica suficientes para o estado-nação menos ainda para as corporações; a escola foi e é colocada de lado faz muito tempo em quase todas as políticas de estado que deveriam contemplar a formação social, cultural, política e econômica dos cidadãos brasileiros. Mais recentemente, então, essas políticas que tenho chamado de despolíticas (BNCC, FUTURE-SE, MILITARIZAÇÃO, TECNICISMO, entre outras coisas que afetam direta e indiretamente a escola) estão desmontando a já sucateada instituição de formação acadêmica brasileira. Assim, é muito evidentemente utópico discutir um trabalho docente mediador em um contexto em que sequer a formação de professores está sendo reconhecida. Entre trabalhar e estudar o trabalho torna-se opção desde que esse trabalho não seja na Educação.

Ao certo, tem ficado muito evidente que propor diálogos entre saberes tem se tornado uma desventura em momentos em que a ciência também tem sido desacreditada pelas políticas de Estado. Assim, parece que a defesa de Boaventura de Sousa Santos (2010), a partir de uma ecologia de saberes, como também de outros vários autores aqui referendados, por exemplo, acerca de uma alternativa para a emergência de conhecimentos e saberes "soterrados" pela ciência enquanto detentora de poderes parece constituir mais como uma ideologia a ser desconsiderada. Pois, uma vez que até mesmo a lógica cartesiana, "penso, logo existo", o saber científico moderno tem perdido forças enquanto constituição como saber hegemônico, em busca de quaís lugares na educação faz sentido ainda lutarmos? Ao certo, a padronização do saber, igualmente de arte, das culturas e até mesmo da forma de educar que se constituiu ao longo dos séculos parecem não ter mais serventia, talvez devamos perguntar ainda qual é a razão de haver nessa sociedade distópica uma noção de educação que não seja delimitadora?

Assim, o objetivo é a perpetuação de subjetividades modernas devotas do consumo cuja única liberdade é obrigatoriamente eleger os líderes que vão continuar garantindo-Ihes a ideia de que a economia é a ciência do que existe, do que há e que o sinal de conformidade de uma vida moral e bem-sucedida é o 
acúmulo de riqueza, mercadoria e propriedade (MIGNOLO, 2014a, p. 7). ${ }^{26}$ (Tradução livre minha)

Os saberes subjetivos (hoje sob a alcunha de conhecimento popular) porque aqueles que os produzem supostamente não pensam, estão cada vez mais sem lugar e não é porque única e exclusivamente se aceita a construção do conhecimento através da ciência que domina a escrita oficial como modo prioritário de produção de conhecimentos. As políticas em evidência em contexto global colocam em cheque e acabam por desqualificar os modos de produção de conhecimentos que emergem dos "saberes populares" e até mesmo o próprio conhecimentos que vinha sendo constituído a partir da ciência de dentro das universidades. O privilégio pela manutenção das classificações coloniais tem rechaçado os corpos subjetivos e os corpora que dominam o escrever, para basearem-se na ideologia do crer e retirar os direitos de ser, sentir e saber, igualmente o de pode fazer e produzir conhecimentos que não estejam desvinculados do giro de capital.

O estado-nação brasileiro atual é um exemplo claro dessa realidade que se vincula a uma das ideias de re-ocidentalização - projeto dos países que quiseram tornar-se potências evidenciando uma lógica colonial baseada no capitalismo em que os Estados Unidos estiveram sempre à frente; ou de des-ocidentalização - em que são projetos de estado-nações, na grande maioria de países latino-americanos, que se sustentaram na lógica capitalista (por meio de comércio de petróleo e outro minerais, por exemplo) promovendo o resurgimento de práticas locais em serviço da globalização. Mas, em contrapartida, todas essas experiências estiveram na contramão de uma descolonialidade dessas nações que, para isso, precisariam voltar-se para a convivência com a Natureza ao invés de destruí-la ou dominá-la para dela arrancar, literalmente, todas as riquezas em prol de fortificação internacional (cf. GÓMEZ, 2014).

Portanto, a tarefa de fazer, pensar e ser descolonial é a cicatrização da ferida e da compulsão viciosa que faz "querer ter": desprender-nos das hierarquias e dos padrões modernos é o primeiro passo para o re-fazermos. $O$ pensamento e o fazer descoloniais, a base do desprendimento, não é um pensamento para "aplicar" (subsidiário da distinção entre teoria e práxis), mas é o próprio ato de pensar, nos tornando, de maneira dialógica e comunitária (MIGNOLO, 2014, p. 7).27 (Tradução livre minha)

Considerando este argumento, ainda é possível insistir na ideia de que a Arte é um gerador de conhecimentos, mas não somente, possível de produção de bem-estar e bem viver por meio da própria arte, especialmente levando em consideração que a Arte é, do mesmo modo que outras, uma disciplina que se mostrou, desde sempre, por mais que não dessem conta (escolas e universidades) aberta ao trabalho como saber transcultural (de diálogos entre saberes (SANTOS, 2010)). Mas, evidentemente, é necessário para isso que os atuais professores em atividades nas Universidades, a lógica colonial/imperial reforça esse lugar uno da produção de um saber, se reciclem para compreender aquele espaço como um lugar da Pluri-versidades (PALERMOS, 2014). Assim, tornar-se-á evidente o reconhecimento da Arte, nem melhor e menos ainda pior, mas igual e tão saber quanto qualquer outra disciplina nas Escolas e Universidades. "Assim, a tarefa da pedagogia descolonial consistirá, paradoxalmente, em educar a escola, uma vez que a escola já foi desescolarizada" (MIGNOLO, 2014, p. 9) ${ }^{28}$ (Tradução livre minha).

\footnotetext{
26“Por eso el propósito es la perpetuación de subjetividades modernas devotas del consumo cuya única liberdad consiste en elegir obligatoriamente a los gobernantes que seguirán sujetándolos a la idea de que la economía es la ciencia de lo existente, de lo que hay y que el signo de cumplimento de una vida moral y exitosa es la acumulación de riqueza, mercancías y propiedades" (MIGNOLO, 2014, p. 7).

27“Por ello, la tarea del hacer, pensar y estar siendo descolonial es la sanación de la herida y de la viciosa compulsión hacia el "querer tener": desprendernos de las normas y jerarquías modernas es el primer paso hacia el re-hacernos. El pensar y hacer descolonial, base del desprendimiento, no es tampoco un pensamiento para "aplicar" (subsidiario de la distinción teoría y praxis), sino que es el acto mismo de pensar haciéndonos, de modo dialogal y comunitário" (MIGNOLO, 2014, p. 7).

28"Así las cosas, la tarea de la pedagogía descolonial consistirá, paradójicamente, en escolarizar la escuela puesto que la escuela ya sido desescolarizada" (MIGNOLO, 2014, p. 9).
} 
Logo, é evidente também a necessária reformulação dos paradigmas da atual noção que temos da Formação de Professores e do Trabalho Docente nas escolas ou nas universidades. Continuar seguindo a lógica da colonização faz quinhentos anos que não deu certo no caso do ensino da Arte no Brasil. Precisamos lutar, contra todos e tudo que pensam o contrário, para resistir e re-existir para formar professores mais sensíveis aos conhecimentos subjetivos como a única alternativa para reconhecimentos daqueles saberes múltiplos. Pois, apenas assim formaremos professores (Arte-mediadores como vim evidenciando) para realização de um Trabalho Docente mediador. Assim, uma argumentação de base descolonização, desocidental, subalterna, fronteiriça, biogeográfica como ato de mediar conhecimentos rediscutirá a subjetivação (padronização) de arte, de cultura e de conhecimentos ainda na atualidade, proponho uma prática mediadora na formação desses professores para o desenvolvimento de um trabalho docente em Arte que horizontalize os saberes, os fazeres, o ser e o sentir arte, cultura e conhecimentos exteriorizados pela imposição colonial do século $\mathrm{XVI}$ e presente ainda hoje por meio da BNCC, do FUTURA-SE, da MILITARIZAÇÃO ou da TECNIZAÇÃO que são ilustrações também de uma colonialidade do poder instaurada desde o advento da globalização no século $X X$ em crescente no século XXI.

Como seria pensar e agir descolonialmente na pedagogia? Em primeiro lugar, e também o início irrecusável de toda a reflexão e atuação nessa direção, para tornar visível e irrefutável de que não há "pedagogia" às cegas, pois, a pedagogia sem modificador é uma pedagogia oficial, em serviço do sistema político e econômico que o sustenta, promove-o e também o deixa cair em favor de ocupações mais "eficientes".

A escola e a educação são, na mentalidade neoliberal, cada vez mais "ineficientes" porque os esforços devem ser colocados no aumento do PBI e não no aprendizado e formação de pessoas que contribuirão para a vida comunitária e plena. A pedagogia descolonial não pode estar a serviço da eficiência, nem da tarefa limitada de formar cidadãos para o Estado-nação (educação liberal), nem apenas na formação de pessoas de fé (educação teológica), mas na busca, através do amor descolonial, daquela humanidade plena que Franz Fanon ambicionou quando acabou de escrever Os condenados da terra, no leito de morte e inundado pela violência da colonialidade, na Argélia e no Terceiro Mundo (MIGNOLO, 2014, p. 9). ${ }^{29}$ (Tradução livre minha)

Ao certo, para fazermos evidenciar a razão de base subalterna e fronteiriça na educação, para fazer que surjam Arte-mediadores ao invés de professores castradores, que desenvolvam um trabalho decente de reconhecimento das diferenças, precisamos fortificar as reflexões, mas mais ainda as atitudes descoloniais e despertar o pertencimento fronteiriço para fazer emergir cada vez mais as reações contramodernas. Pois, de outro modo não faremos emergência de Arte-mediadores, mas castradores em contextos onde a Formação de Professor e o Trabalho Docente, igualmente a subjetividade da arte, das culturas das diferenças e dos saberes não reconhecidos como conhecimentos permanecerão sob as guardas da colonialidade imposta pela manutenção da cientificidade da História da Arte no Ensino de Arte ou das novas regras em imposição pelo estado-nação e pelas grandes corporações que não permitirão descolonizar as fronteiras impostas por esses mesmos sistemas que desconsideram a Arte como capaz de promover co-

\footnotetext{
29" ¿En qué consistiría pensar y actuar descolonialmente en pedagogía? En primer lugar, y también el irrecusable comienzo de toda reflexion y actuación en esta dirección, en hacer visible e irrefutable que no hay "pedagogía" a secas puesto que la pedagogía sin modificador es una pedagogía oficial, al servicio del sistema político y económico que la sustenta, promueve y, también, la deja caer en pro de ocupaciones más "eficientes".

La escuela y la educación son, en la mentalidad neoliberal, cada vez más "ineficientes" pues los esfuerzos deben ponerse en el acrecentamiento de PBI y no del aprendizaje y formación de personas que contribuirán a la vida comunal y plena. La pedagogía descolonial no puede estar el servicio de la eficiencia, ni tampoco a la limitada tarea de formar ciudadanos para el estado-nación (educación liberal), ni tampoco solo en la formación de personas de fe (educación teológica), sino en la búsqueda, a través del amor descolonial, de aquella plena humanidad que ambicionaba Franz Fanon al terminar de escribir Los condanados da la tierra, en el lecho de muerte e inundado por la violencia de la colonialidad, en Argelia e en el Tercer Mundo" (MIGNOLO, 2014, p. 9).
} 
nhecimentos. Cabe aqui agora uma repetição: "No dia em que as universidades públicas ou privadas gerirem a descolonização pedagógica, será porque os processos de descolonização que percebemos na sociedade política já contribuíram para uma mudança radical e para a dissolução da matriz colonial de poder" (MIGNOLO, 2014, p. 2).

Uma formação de professores, um trabalho docente de mediação de/em/com/por meio da arte, de culturas e de conhecimentos das diferenças coloniais romperão com a padronização da subjetividade por meio do uso de forças diversas para o aprendizado de arte ou para a dominação de corpos da exterioridade. Mas não serão o estado-nação, menos ainda as grandes corporações que conseguirão promover essas ações que descolonizarão os sistemas. O primeiro visa à governança, o segundo não abre mão do lucro. Portanto, sem descolonizar as diferentes geopolíticas que são praticadas pelos sistemas, que nos ensinaram forçosamente a perceber o padrão de arte europeu colonial e colonizador ainda hoje no ensinar, no produzir e até mesmo no pesquisar arte e na forma de apreciá-la no Brasil, do mesmo jeito controlam nossas vidas com a necessidade de nascer, crescer para estudar e assim conseguir trabalhar e consumir para suprir a necessidade de querer ter não vamos sequer atravessar a vida tranquilamente. Se é que poderemos dizer que teremos vida!

Acorda Mané!

\section{REFERÊNCIAS}

ACHUGAR, H. Planetas sem boca: escritos efêmeros sobre arte, cultura e literatura. Tradução de Lyslei Nascimento. Belo Horizonte: Ed. da UFMG, 2006.

BASE NACIONAL COMUM CURRICULAR. In: MEC. Base Nacional Comum Curricular. Disponível em: $<$ http://basenacionalcomum.mec.gov.br/>. Acesso em: 27 ago. 2017.

BARBOSA, Ana Mae. "Arte-Educação Pós-colonialista no Brasil: aprendizagem triangular". In: Comunicação \& Educação, v. 2, 1995, p. 59-64. Disponível em: <http:// www.revistas.usp.br/comueduc/article/view/36136>. Acesso em: 26 maio 2016.
"Arte-Educação no Brasil: realidade hoje e expectativas futuras". Tradução: Sofia Fan. Estudos Avançados, vol. 3, no. 7, São Paulo, Set./Dec. 1989, p. 170-182. Disponível em: <http://www.scielo.br/pdf/ea/ v3n7/v3n7a10>. Acesso em: 15 jun. 2018.

BARRETO, Adeline Silva; BESSA-OLIVEIRA, Marcos Antônio. "Pesquisa(s) em Arte(s) - pensando processos investigativos na UEMS". In: BESSA-OLIVEIRA, Marcos Antônio. (Org.). NAV(r)E - Pesquisa e produção de conhecimentos em Arte na Universidade: artista, professor, pesquisador. Campo Grande, MS: Life Editora, 2018, p. 37-48.

BESSA-OLIVEIRA, Marcos Antônio. "Pedagogias das diversalidades - apontamentos iniciais". Comunicação apresentada no X Ciclo de Estudos da Linguagem III Congresso Internacional de Estudos da Linguagem: Descolonialidade e desobediência nos Estudos da Linguagem. Ponta Grossa, Paraná, realizado entre os dias 29 à 31 de julho de 2019. (Texto no prelo).

"Arte, cultura e educação na formação docente com perspectivas dos Estudos de Culturas". In: Movimento - revista de educação, ano 6, n. 11, 2019a, Niterói, RJ, Programa de Pós-Graduação em Educação, Faculdade de Educação da Universidade Federal Fluminense. Disponível em: http://periodicos.uff.br/revistamovimento. Acesso em: 08 out. 2019. (Texto no prelo).

"Intervenções Artísticas como (re)Ação: processos em Artes Visuais". In: Disciplina de Artes Visuais - 2019. Texto desenvolvido e apresentado durante o segundo semestre letivo de 2019 na Disciplina de Artes Visuais. Curso de Artes Cênicas, UUCG da Universidade Estadual de Mato Grosso do Sul, Campo Grande, MS, 2019, p. 1-32. (Texto no prelo).

"Artista, professor, pesquisador: uma matéria em questão nas artes". In: ACADÊMICOS DO $4^{\circ}$ ANO; SALVADOR, Gabriela; ANDRADE, Dora. (Orgs.). IV JART - Jornadas de Artes Cênicas, 2016 - "O artista docente". Curso de Artes Cênicas e Dança. Unidade Universitária Campo Grande - UUCG, Universidade Estadual de Mato Grosso do Sul - UEMS. Realizada nos dias 9, 10 e 11 de junho de 2016a, p. 1-10. 
"O ensino de Artes no Brasil: um breve histó-

rico". In: Ensino de Arte $X$ Estudos Culturais: para além dos muros da escola. São Carlos, SP: Pedro \& João Editores, 2010, p. 53-69.

"Para experimentar, formar, praticar, caminhar é preciso antes ser, sentir, saber bio-geo-grafias no ensino de artes". In: XXVII Congresso Nacional da Federação de Arte/Educadores do Brasil; V Congresso Internacional dos Arte/Educadores; II Seminário de Cultura e Educação de Mato Grosso do Sul [recurso eletrônico]: anais / comissão organizadora, Caciano Silva Lima, Vera Lúcia Penzo Fernandes. - Campo Grande, MS: Federação de Arte/Educadores do Brasil, 2017, p. 240256. Disponível em:/https://faeb.com.br/admin/shared/ midias/1510688060.pdf. Acesso em: 25 maio 2018.

BESSA-OLIVEIRA, Marcos Antônio; NOLASCO. Edgar Cézar; GUERRA, Vânia Maria Lescano; FREIRE, Zélia R. Nolasco dos S. (Orgs.). Fronteiras Platinas em Mato Grosso do Sul (Brasil/Paraguai/Bolívia): biogeografias na arte, crítica biográfica fronteiriça, discurso indígena e literatura de fronteira. Campinas, SP: Pontes Editores, 2017.

BHABHA, Homi K. O local da cultura. Trad. Myriam Ávila, Eliana Lourenço de Lima Reis, Gláucia Renate Gonçalves. $4^{\text {a }}$ Reimpressão. Belo Horizonte: Ed. UFMG, 1998.

BOFF, Leonardo. "Prefácio". In: FREIRE, Paulo. Pedagogia da esperança: um reencontro com a Pedagogia do oprimido. Notas: Ana Maria Araújo Freira. $12^{\mathrm{a}}$ ed. Rio de Janeiro: Paz e Terra, 2005, p. 6-8.

DERRIDA, Jacques. Políticas da amizade. Tradução Fernanda Bernardo. Porto: Campo das Letras - Editores S.A., 2003.

GÓMEZ, Pedro Pablo. "Introducción: trayectorias de la opción estética descolonial". In: GOMÉZ, Pedro Pablo (et. al.). Arte y estética en la encrucijada descolonial II. Compilado por Pedro Pablo Goméz. $1^{\text {a }}$ ed. Ciudad Autónoma de Buenos Aires: Del Signo, 2014, p. 11-30.

HALL, Stuart. Cultura e representação. Organização e revisão técnica: Arthur Ituassu; Tradução: Daniel Miranda e William Oliveira. Rio de Janeiro: Ed. PUC-Rio:
Apicuri, 2016.

LORCA, Javier. "O controle dos corpos e dos saberes. Entrevista com Walter Mignolo". Tradução: André Langer. In: Página/12, 08 de setembro de 2014, p. 1-3. Disponível em: http://www.ihu.unisinos.br/noticias/533148o controledoscorposedossaberesentrevistacomwaltermig nolo?tmpl=component\&amp;print=1\&amp;page=. Acesso em: 29 abr. 2016.

MICHAELLIS - Dicionário Brasileiro da Língua Portuguesa. Disponível em: <https://michaelis.uol.com.br/ moderno-portugues/>. Acesso em: 01 ago. 2019.

MIGNOLO, Walter. "Desafios decoloniais hoje". Trad. de Marcos de Jesus Oliveira. Epistemologias do Sul: Pensamento Social e Político em/desde/para América Latina, Caribe, África e Ásia, v.1, n. 1, Foz do Iguaçu/PR: Universidade Federal da Integração Latino-Americana, p. 12-32. 2017. Disponível em: https://revistas.unila.edu. br/epistemologiasdosul/article/view/772/645.

Acesso em: 27 mar. 2018.

"Aesthesis descolonial". In: GOMÉZ, Pedro Pablo (et. al.). Arte y estética en la encrucijada descolonial II. Compilado por Pedro Pablo Goméz. 1. ed. Ciudad Autónoma de Buenos Aires: Del Signo, 2014, p. 31-56.

"Prefacio". In: PALERMO, Zulma. Para una pedagogia decolonial. $1^{a}$ ed. Ciudad Autónoma de Buenos Aires: Del Signo, 2014a. (El desprendimento / Walter Mignolo), p. 7-9.

"Habitar los dos lados de la frontera/teorizar en el cuerpo de esa experiencia". In: Revista IXCHEL. Volúmen I, San José, Costa Rica, 2009, p. 1-22. Disponível em: http://www.revistaixchel.org/attachments/047_Habitar\%20los\%20dos\%20lados\%20art_\%20Walter\%20 Mignolo.doc\%29.pdf. Acesso em: 30 maio 2013.

"Desobediência epistêmica: a opção descolonial e o significado de identidade em política". In: Cadernos de Letras: Universidade Federal Fluminense - Instituto de Letras. Dossiê: Literatura, língua e identidade. $n$. 34, Niterói, RJ. 2008, p. 287-324. Disponível em: http:// www.uff.br/cadernosdeletrasuff/34/traducao.pdf. Acesso em: 16 de nov. 2012. 
Histórias locais / projetos globais: colonialidade, saberes subalternos e pensamente liminar. Tradução Solange Ribeiro de Oliveira. Belo Horizonte: Editora UFMG, 2003.

MOREIRA, Antonio Flávio; CANDAU, Vera Maria. (Orgs.). Multiculturalismo: diferenças culturais e práticas pedagógicas. 10. ed. Petrópolis, RJ: Vozes, 2013.

NELSON, Cary; TREICHLER, Paula A.; \& GROSSBERG, Laerence. "Estudos Culturais: uma introdução". In: SILVA, Tomaz Tadeu da. (Org.). Alienígenas na sala de aula: uma introdução aos estudos culturais em educação. Petrópolis, RJ: Vozes, 1995. (Coleção estudos culturais em Educação).

NOLASCO, Edgar Cézar. "Descolonizando a pesquisa acadêmica: uma teorização sem disciplinas". Acervo do autor. 2019, texto no prelo, p. 1-22.

PALERMO, Zulma. Para una pedagogia decolonial. $1^{\text {a }}$ ed. Ciudad Autónoma de Buenos Aires: Del Signo, 2014. (El desprendimento / Walter Mignolo).

QUIJANO, Aníbal. Colonialidade do poder, eurocentrismo e América Latina. In: LANDER, Edgardo. (Org.). A colonialidade do saber: eurocentrismo e ciências sociais. Perspectivas latino-americanas. Colección Sur Sur, CLACSO, Ciudad Autónoma de Buenos Aires, Argentina, setembro 2005, p. 227-278. Disponível em: http://bibliotecavirtual.clacso.org.ar/ar/libros/lander/pt/ Quijano.rtf. Acesso em: 31 maio 2019.

SANTIAGO, Silviano. Uma Literatura nos Trópicos. 2 ed. Rio de Janeiro: Rocco, 2000.

SANTOS, Boaventura de Sousa; HISSA, Cássio E. Viana. Transdisciplinaridade e ecologia de saberes. In: HISSA, Cássio E. Viana. (Org.). Conversações: de artes e de ciências. Belo Horizonte: Editora UFMG, 2011, p. 17-34. (Humanitas).

SANTOS, Boaventura de Sousa. Para além do pensamento abissal: das linhas globais a uma ecologia de saberes. In: SANTOS, Boaventura de Sousa; MENESES, Maria Paula. (Orgs.). Epistemologias do sul. São Paulo: Cortez, 2010, p. 31-83.
SANTOS, Kelly Queiroz dos; BESSA-OLIVEIRA, Marcos Antônio. "'Mediação' como possibilidade para o ensino de Arte". In: BESSA-OLIVEIRA, Marcos Antônio. (Org.). Anais da Jornada de Artes da UEMS 2018: para que serve o ensino das artes na escola? Anais... Campo Grande (MS) UEMS - Universidade Estadual de Mato Grosso do Sul, UUCG - Unidade Universitária Campo Grande, 2018. Disponível em: https//www. even3.com.br/anais/jart/109655-MEDIACAO-COMO-POSSIBILIDADE-PARA-O-ENSINO-DE-ARTE. Acesso em: 08 out. 2019.

SKLIAR, Carlos. (Org.). Derrida \& a Educação. Belo Horizonte: Autêntica Editora, 2005. 